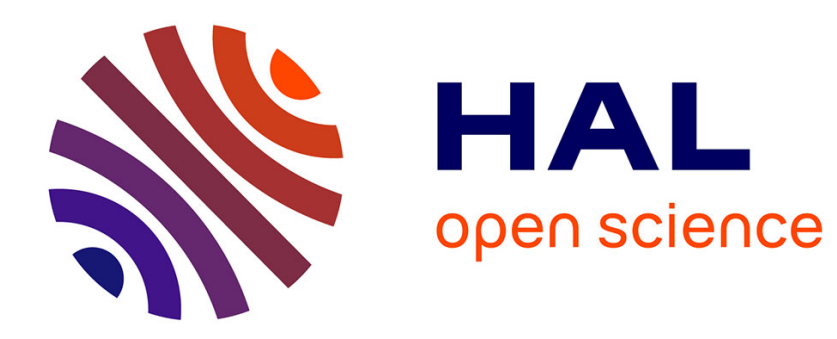

\title{
Photon Converters for Photovoltaics
}

Aline M. Nonat, Thomas Fix

\section{To cite this version:}

Aline M. Nonat, Thomas Fix. Photon Converters for Photovoltaics. Advanced Micro- and Nanomaterials for Photovoltaics, Elsevier, pp.121-151, 2019, 10.1016/B978-0-12-814501-2.00006-2 . hal02341164

\section{HAL Id: hal-02341164 \\ https://hal.science/hal-02341164}

Submitted on 15 Sep 2020

HAL is a multi-disciplinary open access archive for the deposit and dissemination of scientific research documents, whether they are published or not. The documents may come from teaching and research institutions in France or abroad, or from public or private research centers.
L'archive ouverte pluridisciplinaire HAL, est destinée au dépôt et à la diffusion de documents scientifiques de niveau recherche, publiés ou non, émanant des établissements d'enseignement et de recherche français ou étrangers, des laboratoires publics ou privés. 


\section{Photon converters for photovoltaics}

Aline Nonat

IPHC, CNRS and University of Strasbourg, France

Thomas Fix

ICube laboratory, CNRS and University of Strasbourg, France

\section{Downshifting and downconversion}

Photovoltaics has been an exploding field of research for the last forty years and is now dominated by the reduction of costs. Numbers of technologies and advanced concepts have been developed in order to reach the Shockley-Queisser boundary, including improved electronic properties using very narrow junction(s), low doping levels or very thin window/buffer layers where they exist. "Third generation" solar cells are being investigated, with sophisticated structures, such as multijunction,[1] heterojunction[2] or intermediate band gap.[3] However, it is the cost of a solar cell, no doubts about its performance, which decides its fate and most of these advanced techniques are difficult and/or expensive to implement at industrial level. Moreover, most of the current cell technologies still make a sub-optimal use of the incident solar photons. In single bandgap systems, incident photons which do not fit to the bandgap are lost and these losses represent about $50 \%$ of the losses in the conversion into electricity: thin film chalcogenides technologies (CdTe and CIGS) suffer from parasitic optical absorption in UV and blue spectral ranges and such phenomenon is also observed for Si cells (when they are not optimized for UV range) and multijunctions cells (CdS/CdTe[4],...), especially those produced in a production environment, due to the mismatch of photocurrents in top and bottom cells. Moreover, hybrid organic-inorganic perovskite solar cells[5] and organic photovoltaic devices (OPV) and dye-sensitized solar cells (DSSC) might also suffer from low UV harvesting. [6] The window of performance efficiency of the main technologies together the major loss mechanisms at short wavelengths are summarized in Table 1.

\begin{tabular}{|c|c|c|c|}
\hline Technology & Cell type & $\begin{array}{l}\text { Window of } \\
\text { performance } \\
\text { efficiency* }\end{array}$ & Major loss mechanism at short $\lambda$ \\
\hline \multirow{3}{*}{ Silicon } & $c-\mathrm{Si}$ & \multirow{2}{*}{$\approx 450-1000 \mathrm{~nm}$} & \multirow{2}{*}{$\begin{array}{l}\text { Emitter recombination, increased } \\
\text { reflectance and absorption of the ARC }\end{array}$} \\
\hline & $a-\mathrm{Si}$ & & \\
\hline & $m c-S i$ & $\approx 450-1050 \mathrm{~nm}$ & $\begin{array}{l}\text { Absorption in TCO layer and emitter } \\
\text { recombination }\end{array}$ \\
\hline \multirow{3}{*}{ Thin-film } & GaAs & $\approx 550-900 \mathrm{~nm}$ & $\begin{array}{l}\text { Absorption in AlGaAs or InGaAs window } \\
\text { layer }\end{array}$ \\
\hline & CIGS & $\approx 450-1000 \mathrm{~nm}$ & \multirow{2}{*}{$\begin{array}{l}\text { Absorption in buffer layer (i.e. CdS) and } \\
\text { TCO layer }\end{array}$} \\
\hline & CIGSSe & $\approx 450-1050 \mathrm{~nm}$ & \\
\hline Perovskite & perovskite & $\approx 400-750 \mathrm{~nm}$ & $\begin{array}{l}\text { The major limitation is the } \\
\text { photodegradation caused by prolonged } \\
\text { UV illumination }\end{array}$ \\
\hline \multicolumn{3}{|c|}{ All (except a-Si and CdTe) } & Absorption from glass and encapsulant \\
\hline
\end{tabular}

*defined as the region where EQE $\geq 0.95 \times(E Q E)_{\max }$ and based on references [7], [8] and [5]. 
Table 1. Window of performance efficiency in state-to-the art devices and major loss mechanisms at short wavelengths for common solar cells technologies (Adapted from ref. [7], [8] and [5]). ARC = anti-reflective coating, $\mathrm{TCO}=$ transparent conducting oxide, $\mathrm{OPV}=$ Organic photovoltaic device, DSSC = Dye-sensitized solar cell.

Photon conversion is a very appealing strategy to improve the spectral response of most cells without adding substantially to the cost or lowering their yield.[9]'[10]'[11]'[12] Three conversion concepts have been proposed and explored to date. Downshifting and downconversion aim to reduce the loss of photons of higher energy than the bandgap and up conversion is used to remediate to the non-absorption of photons with lower energy than the bandgap.

In the case of downshifting and downconversion, photon conversion is achieved by simply adding an electronically passive conversion layer (plastic, glass or crystalline sheet) in front of the cell ("add-on technology") or by doping the solar module encapsulants with photonic converters (PCs) (Figure 1). Sheets of downshifting materials have also been used as low cost solar concentrators and in these devices, cells are placed along the edges of the sheet instead of on optical series.[13]'[14]'[15]'[16] Finally, these light downshifting (LDS) materials have been incorporated in a protecting plate for the coloration of solar cell modules. In such devices, the part of the energy loss due to the coloration (the outward scattering caused by the isotropic emission of the fluorescent light) is compensated by the additional energy gain due to downshifting. As an example, coloration in green yields a $2.7 \%$ increase in energy conversion efficiency.[17]

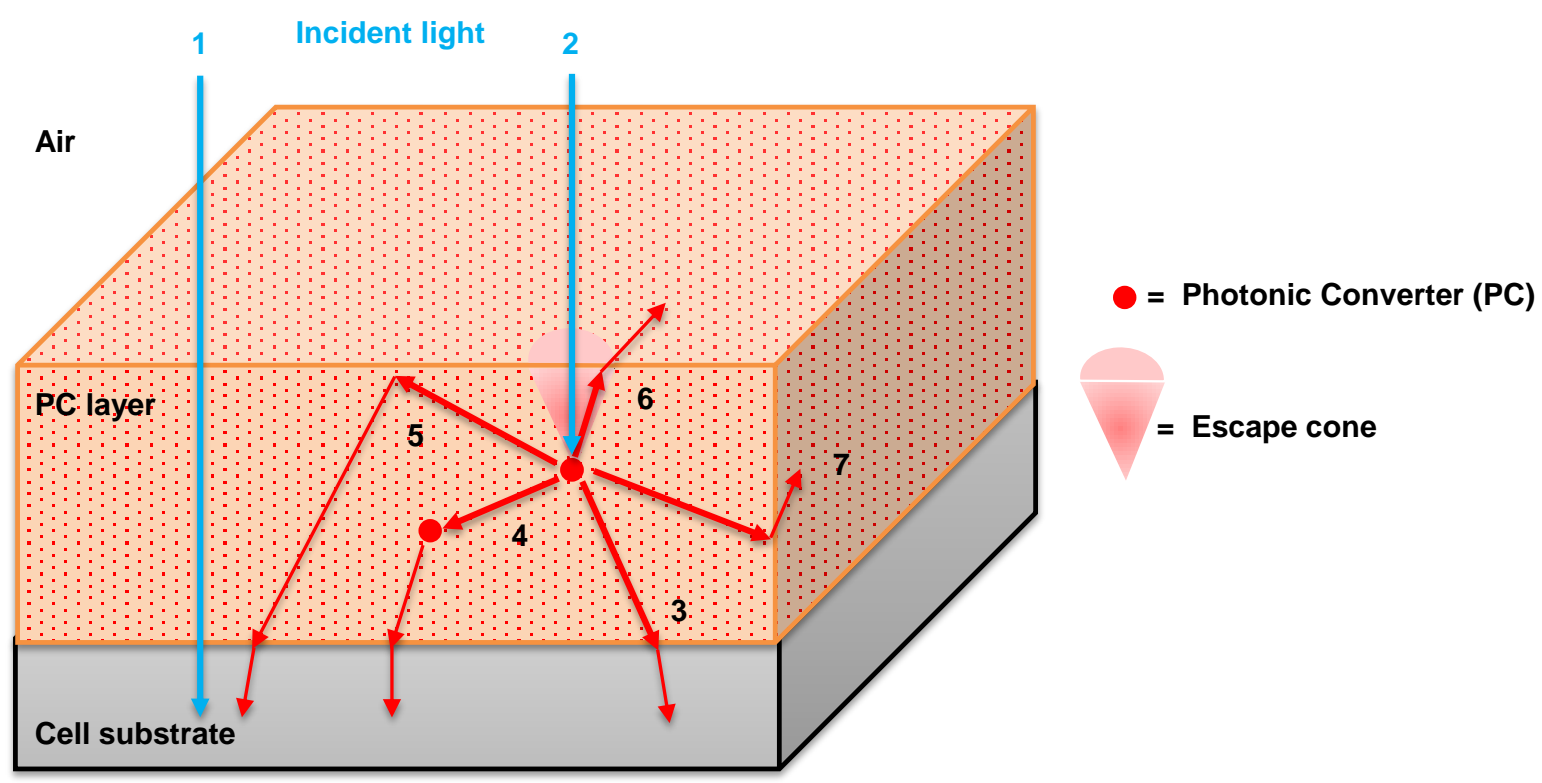

Figure 1. Representation of the "add-on" technology used for downshifting and downconversion on a solar cell showing the main optical pathway in the case of an isotropic model. Incident light will be either directly transmitted to the cell (1) or absorbed by a PC (2) and then converted into photons of higher energy. A majority will be directly emitted to the cell (3) or via re-absorption by another PC (4) or by internal reflection (5). A fraction of the converted light will be lost through the escape cone (6)[18] or through the side of the module (7).

The PCs convert each UV photon into one (downshifting) or two (downconversion, also called quantum cutting) photons at longer wavelengths (visible or NIR). The three main processes are 
depicted in Figure 2. Downshifting involves a typical Stokes mechanism with a single emitter in which the energy of the emitted photon (E2) is lower than the populated excited states of the PC. This difference is called 'Stokes shift' and is due to non-radiative quenching (dotted black arrow in Figure 2a). In the case of downconversion, depopulation of the excited state E2 leads to the emission of two photons of energy E1. This can be achieved by using a single emitter such as quantum dots (Figure 2b).[19]'[20]'[21] However, in the majority of the cases, the downconversion process has been dictated by using donor/acceptor triads with matching excited states. The mechanism is presented in Figure $2 \mathrm{c}$ in which the depopulation of the excited state of the donor (E2) occurs by non-radiative quenching then by energy transfer to the acceptors to finally observe the simultaneous emission of two photons of energy E1. Such properties (Figure 2c) can be obtained by using materials or nanoparticles doped with lanthanide(III) ions (see § 2).[22]'[23]'[24]

a)

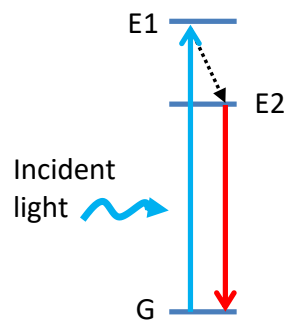

Downshifting b)

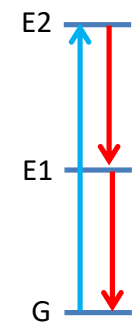

c)

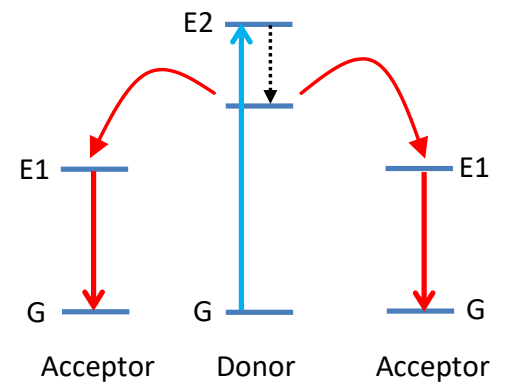

Downconversion

Figure 2. Schematic representation of the downshifting (a) and downconversion mechanisms with a single emitter (b) and with donor-acceptor triads (c).

\subsection{Downshifting}

\subsubsection{Prerequisite}

From organic dyes to inorganic glasses, including coordination complexes and nanoparticles, a whole range of luminescent materials (fluorescent and phosphorescent) are available and have been implemented on solar cells.[25] In this field, the measurement of the spectral response of a cell is the key to demonstrate the effect of photonic conversion and to discriminate from passivation and antireflective effects. In particular, the external quantum efficiency (EQE), defined as the ratio of the number of extracted free charge carriers to the number of photons incident on the front surface of the cell or the internal quantum efficiency (IQE, $I Q E=E Q E /(1$ - reflectance $)$ ) are measured.

From these studies, the following specifications can be enlightened for the design of efficient luminescent downshifting materials.

-High photo- and thermal stabilities, strong resistance to humidity variations and high mechanical strength. Photonic converters with prolonged photostability over more than 25 years are required. In that context, the stability of organic dyes is often questioned and a lot of dyes are known to 
photobleach after a period of time in sunlight. Even perylene and naphtalimide-based dyes (Lumogen ${ }^{\circledR} \mathrm{F}$ dyes), which have an improved photostability under sunlight irradiation, are known to degrade with illumination at $\lambda<345 \mathrm{~nm}$.[26]'[27]

-High quantum efficiencies. The quantum efficiency of a dye or of a luminescent material can be obtained by measuring its absolute quantum yield, ie. the number of photons emitted per incident absorbed photon. This is an intrinsic parameter which depends on the environment of the photon converter (ie. embedded in a polymeric material, as a glass or crystalline sheet) since it is strongly affected by phonons, its concentration in the material (due to possible re-absorption, see below) and in some cases, by the excitation wavelength (in the case of multiple absorption bands or excimer and exciplex formation). A large number of downshifting materials with high quantum efficiencies are available, including fluorescent materials or polymers doped with organic dyes or nanoparticles such as quantum dots, transition metal phosphors, or rare-earth coordination complexes.

-Strong absorption coefficients in the region of interest. The absorption spectra are strongly dependent of the type of photon converter considered. For instance, quantum dots have extra-broad absorption bands ranging from the UV to the visible,[28] chromophoric units used in organic dyes or coordination complexes have usually strong and gaussian-shaped absorption bands, whereas transition metal phosphors[29] or glasses doped with lanthanides have very weak absorption coefficients.[24] Moreover, the absorption window of interest need to be tuned in accordance to the external quantum efficiency profile of the photovoltaic cell considered.

-Large Stokes or pseudo-Stokes shifts. These shifts are defined as the wavelengths separation between the two nearest absorption and emission peaks. In the case of an overlap between the absorption and emission bands, reabsorption of the emitted radiations occurs, also called inner-filter effect. Such phenomenon is typical for organic dyes, which generally have Stokes shifts less than 0.5 $\mathrm{eV}$ and is responsible for a decrease of their quantum efficiencies from $100 \%$ at very low concentration to $70 \%$ or less in practice.[30] In order, to circumvent that problem, compounds with excited-state intramolecular proton-transfer (ESIPT) properties or aggregation-induced emission are being developed.[31]'[32]'[33] ESIPT is a photochemical process that produces emission from a tautomer with a different electronic structure than that of the original excited state and leads to large Stokes shifts.[34] Another alternative consists in using rare earth coordination complexes mainly Eu(III) complexes- with pseudo-Stokes' shifts up to $300 \mathrm{~nm}$ (i.e. $4.3 \mathrm{eV}$ ) and no self-absorption.

- Optical efficiency. The optical efficiency $\eta_{\text {opt }}$ is defined as the number of photons transmitted into the solar cell divided by the number of incoming photons incident on the upper surface. This efficiency can be estimated in the non-absorbing region from the refractive index of the different layers and from the Fresnel coefficients at the various boundaries.[35] In the region where photon conversion occurs, several additional parameters have to be taken into account such as the reflection from the upper surface of DS material, the quantum efficiency, the escape of some of the fluorescent light through the upper surface by the escape cone at angle $\theta i<\theta c=\sin ^{-1}(1 / n \lambda)$ (Figure 1), and the possible re-absorption by inner-filter effect. These losses can be calculated using weighted Monte Carlo Ray tracing.[36]'[37]'[38]'[39] With the aim to prevent reflection losses at the lower boundaries, the sheet of downshifting material should ideally be free of defects and exhibit high transparency for photons which are well converted by the solar cell and high light-trapping efficiency. As a 
consequence, it should possess a higher refractive index than that of the cell substrate or of the thinfilm anti-reflection coating.

\section{-Easy availability and low cost.}

\subsubsection{Host materials}

Polymeric materials, such as poly-methyl methacrylate (PMMA) and poly-ethylene vinyl acetate (EVA) are transparent in the visible region, possess good mechanical properties and can easily dissolve most organic dyes. They are considered as a good and cheap host for LDS materials[7] and are deposited usually deposited on the cells by spin-coating, drop-casting or doctor blading.

On the other hand, these polymeric materials, including EVA, which is the standard encapsulant used for c-Si solar cells, degrade upon prolonged UV illumination and therefore they are doped with UV stabilizers (i.e. absorbers) to circumvent that issue. It is clear that there is a significant improvement of optical efficiency to be gained by the development of new host materials with improved properties.Several groups have considered the use alternative waveguides with long photostability and appealing properties, such as fluoropolymers,[40] silicates or silicon nitride,[41]'[42] or organosilanes such as silesquioxanes,[43] ormosil[44] or ureasil.[45] Finally, new strategies using nanopatterning by soft imprint lithography have proven to significantly improve the antireflection properties and therefore increase the photoluminescence intensity compared with the non-pattern analogues.[46]'[47] As an example, the process used by M. Shin and H. Ko for the fabrication of a moth-eye-shaped nanopatterned poydimemethyloxane (PDMS) layer doped with QDs using a Si mold is presented on Figure 3. This layer is prepared separately from the device and can easily be attached and detached. 
(a)
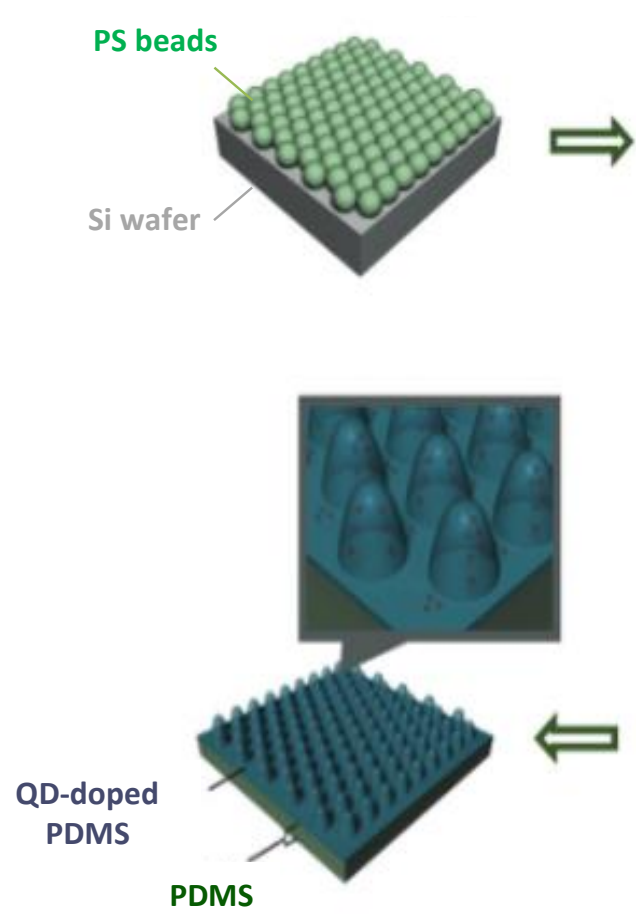

(f) (b)
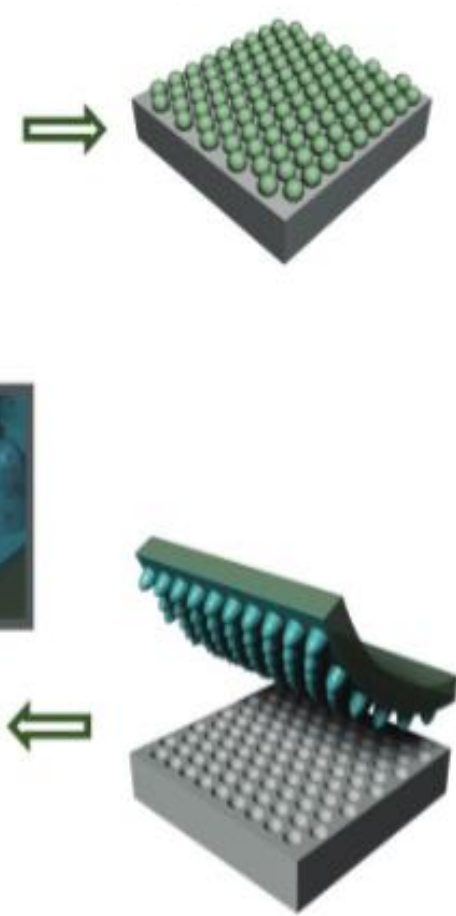

(e) (c)

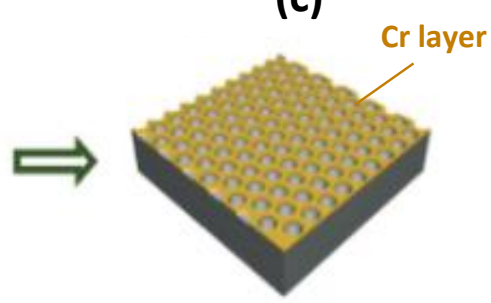

$\sqrt{ }$
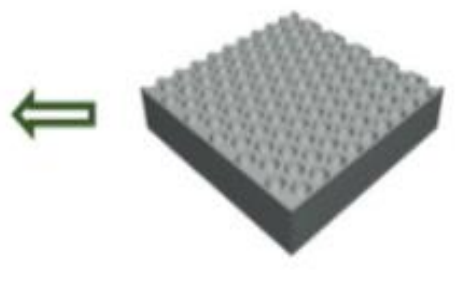

(d)

Figure 3. Fabrication process of a moth-eyed nanopatterned QD-embedded PDMS film. (a) Realization of a self-assembled mask of PS beads on a Si wafer. (b) Etching of the PS beads by $\mathrm{O}_{2}$ plasma. (c) Deposition of a $\mathrm{Cr}$ layer and rinsing of the PS beads. (d) Removal of the Cr mask and application of an anti-adherent layer. (e) Spin-coating aof a h-PDMS/QDs solution in xylene/toluene and baking. (f) Peeling-off in ethanol. Adapted with permission from ref [46]. Y.H. Ghymn, K. Jung, M. Shin, H. Ko, Nanoscale 7 (2015) 18642-18650.

For more detailed and comprehensive review on the host materials, the reader is invited to read dedicated reviews on that topic.[48]'[49]'[50]'[51]'[52]

\subsubsection{Downshifting converters}

Three main categories of downshifting photonic converters have been investigated. Organic dyes or fluorophores are highly conjugated hetero aromatic molecules. Their highly delocalized electrons are responsible for their high absorption coefficients and their fluorescence properties upon excitation. A wide range of dyes (coumarin, rhodamine, perylene and naphtalimide derivatives rubrene, see Figure 4) are available with excitation energy from UV to visible and emission spectra from visible to the near infrared region. In particular, the perylene bisimide Lumogen Red 305 ( $\Phi=97 \%$ in PMMA) is one of the most studied in the field. Other Lumogen $\mathrm{F}$ dyes (Figure $4, \mathrm{~b}, \mathrm{~d}$ and e) have quantum yields above 0.94 in chloroform and have an increased photostability. The lifetime of their excited state is of the order of few nanoseconds.[30]'[53]Nevertheless, their major drawbacks come from reabsorption and/or aggregation processes, resulting in significant emission quenching and photostability issues upon long term illumination. 
a)

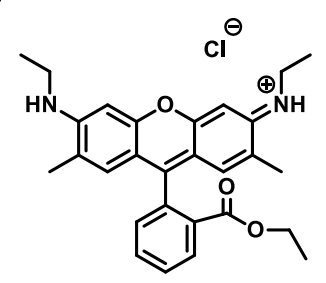

d)

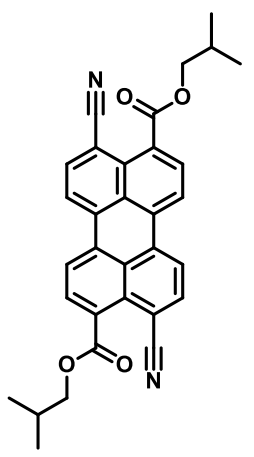

g)

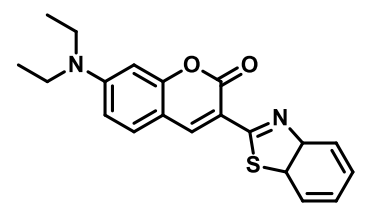

b)<smiles></smiles>

c)<smiles>CCCCCC(CC)N1C(=O)c2ccc(OC)c3c(OC)ccc(c23)C1=O</smiles>

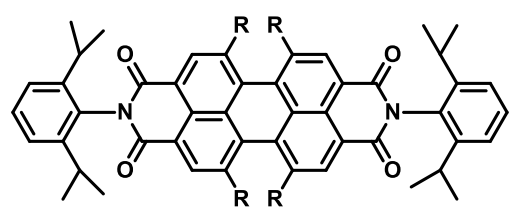

e) $\mathrm{R}=\mathrm{H}$<smiles>[2H]COc1ccccc1</smiles>

h)<smiles>c1ccc(-c2c(-c3ccccc3)c(-c3ccccc3)c(-c3ccccc3)c(-c3ccccc3)c2-c2ccccc2)cc1</smiles>

Figure 4. Most common luminophores used in LDs materials. a) 2-[6-(ethylamino)-3-(ethylimino)-2,7dimethyl-3H-xanthene-9-yl]benzoic acid ethyl esther (Rhodamine 6G), b) Perylene, c) 6,7-dimethoxy2-(octan-3-yl)-1H-benzo[de]isoquinoline-1,3(2H)-dione (Lumogen F Violet 570), d) diisobutyl 4,10dicyanoperylene-3,9-dicarboxylate (Lumogen $F$ Yellow 083), e) perylene-3,4,9,10 tetracarboxyloc acid-bis(2'-6'diisopropylanilide)(Lumogen F Orange 240) , f) perylene-1,7,8,12-tetraphenoxy-3,4,9,10 tetracarboxyloc acid-bis(2'-6'diisopropylanilide) (Lumogen F Red 305), g) 7-(diethylamino)-3-(3a,7adihydrobenzo[d]thiazol-2-yl)coumarin (Coumarin 540) and h) Rubrene.

Quantum dots are semiconducting nanoparticles and their optical properties are due to electronic movements from the valence to the conduction band (absorption) and vice-versa (fluorescence). Emission spectra from blue to NIR can be obtained by changing the composition and/or the architecture of the nanoparticles (i.e. using core-shell,[54] alloyed[55] or NPs doped with transition metals).[56] Moreover, as the confinement energy depends on the quantum dot's size, both absorption and emission properties can be tuned by changing the size of their core (usually in the 2 to $6 \mathrm{~nm}$ ).[54] Although very appealing, the incorporation of QDs in LDS materials remains challenging because of the strong tendancy to QDs to aggregate or to interact with the host medium, thereby altering their photoluminescence properties.

Rare-earth ions, and in particular lanthanides have very appealing spectroscopic properties arising from their $4 f \rightarrow 4 f$ transitions. Because of the electronic configuration of lanthanide ( $[X e] 4 f^{n}, n=0$ to 14), $4 f$ electrons involved here are very little perturbed by the chemical environment, resulting in characteristics in line-like emission bands, high photoluminescence quantum yields and lifetimes of the excited states of few milliseconds for visible emitters such as Tb"' and Eu'".'[24] On the other hand, f-f electronic transitions are also characterized by very weak absorption cross sections. [29] Much higher absorption properties are obtained using an antenna, which absorbs and transfers the energy to the emitting $L^{\prime \prime \prime}$ ion through three successive energy transfers: (i) excitation of the 
antenna to its singlet excited state $\left(\mathrm{S}_{1}\right)$, (ii) intersystem crossing to the first excited triplet state $\left(\mathrm{T}_{1}\right)$ of the antenna and (iii) intramolecular energy transfer from $T_{1}$ to the accepting level of the lanthanide $(\operatorname{Ln})$. This approach is commonly used in the development of luminescent lanthanide coordination complexes. $^{57}$

Great cares must be taken in the choice of the organic antenna in order to observe efficient energy transfer from $\mathrm{T}_{1}$ to $\mathrm{Ln}^{*}$. Numerous studies are dedicated to the optimization of these energy transfer processes, while shifting the absorption spectrum of the antennae to the visible region. [58]'[59]'[60] Ternary complexes with $\mathbf{6}$-diketonate ligands are particularly appealing for such application (Tables 2 and 3).[61]'[62]'[63]'[64]'[65]'[66],[67],[68]

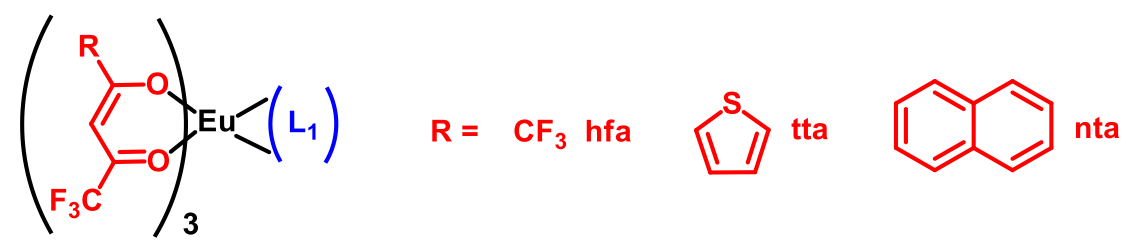

\begin{tabular}{|c|c|c|c|c|}
\hline$L_{1}$ & $\beta$-diketone & $\Phi_{\text {solid }}(\%)^{\mathrm{a}}$ & $\Phi_{\text {polymer }}(\%)^{\mathrm{a}}$ & refs \\
\hline \multirow[t]{2}{*}{ phen } & tta & 69 & $\begin{array}{l}\text { EVA, } 65 \\
\text { PMMA, } 73\end{array}$ & $62,63,59$ \\
\hline & hfa & & PMMA, 85 & 66 \\
\hline \multirow[t]{2}{*}{ Ephen } & tta & 78 & & 61 \\
\hline & nta & 76 & & 61 \\
\hline tdphen & tta & & & 60 \\
\hline bpbpy & tta & 79 & & 10 \\
\hline \multirow[t]{3}{*}{ dpepo } & tta & 82 & & 61 \\
\hline & nta & 82 & & 61 \\
\hline & hfa & & $\begin{array}{l}\text { PMMA, } 85 \\
\text { EVA, } 88\end{array}$ & $\begin{array}{l}66 \\
64\end{array}$ \\
\hline
\end{tabular}

a Upon excitation at $340 \mathrm{~nm}$. Estimated error is $\pm 15 \%$.

Table 2. Selection of bright Eu"' ternary complexes ( $L_{1}=$ bidentate ligand) with $Q Y$ in the $70 \%$ range or above in the solid state. 


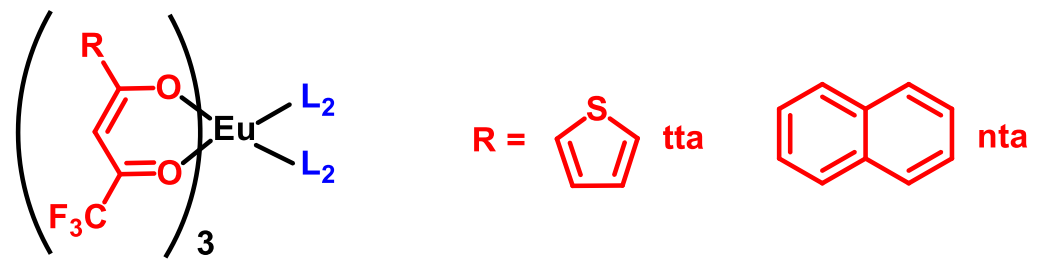

\begin{tabular}{|l|l|l|l|l|}
\hline \multicolumn{2}{|l|}{$\mathbf{L}_{2}$} & $\beta$-diketone & $\Phi_{\text {solid }}(\%)$ & refs \\
\hline tppo & dbso & tta & $73^{\mathrm{b}}$ & 67 \\
\cline { 3 - 5 } & & &
\end{tabular}

a Upon excitation at $340 \mathrm{~nm}$. ${ }^{\text {b }}$ Upon excitation at $360 \mathrm{~nm}$. Estimated error is $\pm 15 \%$.

Table 3. Selection of bright Eu'l' ternary complexes ( $L_{2}=$ monodentate ligand) with $Q Y$ in the $70 \%$ range or above in the solid state.

With the aim to shift the excitation spectrum towards higher wavelengths, antennae with extended conjugation have been used. However, only a fine and careful tuning of the singlet state of the antenna is possible in order to maintain the quantum yields above $70 \%$, since back transfer can occur from the Eu(III) excited state to the ${ }^{3} \mathrm{~T}$ state and quench the emission. This is nevertheless possible and $\mathrm{Eu}(\mathrm{III})$ complexes bearing nta or tdphen units are good examples.

The pro and cons of the main downshifting photonic convertors are summarized in Table 4.

\begin{tabular}{|c|c|c|}
\hline Category & Pros & Cons \\
\hline Organic dye & $\begin{array}{l}\text {-price and accessibility } \\
\text {-high absorption } \\
\text { coefficients } \\
\text {-QY close to unity for } \\
\text { visible emitters }\end{array}$ & $\begin{array}{l}\text {-small Stokes-shifts } \\
\text {-reabsorption (inner-filter } \\
\text { effect) } \\
\text {-aggregation } \\
\text {-photostability }\end{array}$ \\
\hline Quantum dot & $\begin{array}{l}\text { - very high absorption } \\
\text { coefficients } \\
\text {-QY in the } 75-95 \% \text { range } \\
\text { for visible emitters } \\
\text {-fine tuning of the } \\
\text { emission spectra is } \\
\text { possible }\end{array}$ & $\begin{array}{l}\text {-aggregation and surface } \\
\text { interaction strongly decrease } \\
\text { the } \mathrm{QY} \\
\text {-material engineering may } \\
\text { be difficult } \\
\text { - reabsorption } \\
\text { - price } \\
\text {-toxicity when } \mathrm{Cd} \text { and } \mathrm{Pb} \text { are } \\
\text { used }\end{array}$ \\
\hline Rare-earth ion & - stability & $\begin{array}{l}\text { - very weak absorption cross } \\
\text { sections }\end{array}$ \\
\hline
\end{tabular}




\begin{tabular}{|l|l|l|}
\hline $\begin{array}{l}\text { Rare-earth } \\
\text { coordination } \\
\text { complexes }\end{array}$ & $\begin{array}{l}\text { large pseudo-Stokes } \\
\text { shifts }\left(>600 \mathrm{~cm}^{-1} \text { for } \mathrm{Eu}^{\prime \prime \prime}\right. \\
\text { complexes) } \\
\text { - stability } \\
\text {-moderate absorption } \\
\text { coefficients } \\
\text {-QY close to unity for } \\
\text { some visible emitters }\end{array}$ & $\begin{array}{l}\text { lanthanide first excited } \\
\text { states }\end{array}$ \\
&
\end{tabular}

Table 4 . Pros and cons of the three main categories of downshifting photonic converters for LDS materials.

\subsubsection{Devices}

The pioneering examples have been described by H.J. Hovel, R. T. Hodgson and J. M. Woodwall in the late 1970s, on GaAlAs-GaAs, CdS cells and p-i-n amorphous Si devices.[69] They studied two types of downshifting materials: (i) a PMMA polymer doped with several organic dyes including Rohm-Hass 2154, Coumarin 540, Rhodamine 6 G and rubrene (Figure 4) and (ii) a chromium-doped sapphire (ruby) glass with about $100 \%$ quantum efficiency. These first studies were rather inconclusive on commercial Si devices for which only ruby fluorescent sheets have resulted in improved high-energy spectral responses. However, experiments with thin-film solar cells were more encouraging. As an example, coating GaAlAs-GaAs cells with Rohm-Haas $2154^{\circ}$, led to significant increase of the quantum efficiency of the fluorescent sheet solar cell combination at high energy $(+40 \%$ at $3.0 \mathrm{eV})$ and resulted in an increased AMO efficiency for the cells (from $\eta=14$ to $15 \%$, under air mass zero AMO illumination). Very promising results were obtained from a CdS cell coated with rubrene, despite its very small Stokes shift. 36 years after this pioneering work, the Japanese brand Nitto Denko Corporation launched its first PV panel enhancing sheets based on down shifting.[70] The main device developments based on a downshifting strategy are presented below. The list of the examples detailed in the following sections is not exhaustive and our attention has been focused on illustrating, for each technology, the versatility of the approaches used to date.

\subsubsection{Si}

Although the first experiences by Hovel et al on Si cells were rather disappointing,[69] the use of a LDS material remains interesting for industrial type single-junction silicon solar cells which have a poor blue response. Indeed, standard screen-printed mc-Si production-line solar cells exhibit poor EQE at $\lambda<500 \mathrm{~nm}$, which is due to higher reflection and absorption by anti-reflective coating (which are optimized for higher wavelengths) and increased recombination. In some case, these losses can represent up to $50 \%$. $c$-Si cells display better performances at short wavelengths but below $400 \mathrm{~nm}$, reflectance and absorption by the glass and the encapsulant (which incorporate a UV absorber to prevent yellowing of the encapsulant polymer) are again increasing, the effect of adding a LDS material might also be investigated in such devices. First theoretical modelisation performed by van Sark et al, based on nanoparticules emitting at $608 \mathrm{~nm}$ with absolute quantum yield of 0.8 , were very optimistic but based on many assumptions.[71] Since then, more realistic models based on raytracing analyses have been developed by McIntosh with lumogen-doped PMMA[72] for which the simulated results are in relatively good agreement with experimental results : $+40 \%$ EQE is observed 
at short wavelengths $(\lambda<400 \mathrm{~nm})$, resulting in a relative increase of the conversion efficiency of the Si cell of $c a .1 \%$ under AM1.5G illumination. These studies have recently been confirmed and completed with two novel theoretical models.[73]'[74]

Both theoretical and experimental investigations on $m c$-Si and $c$-Si have been reviewed by Klampaftis et al.[7] Number of organic dyes in PMMA, PVA or EVA have been tested and strong discrepancies are observed in the first studies, which mostly arise from the differences in photostability of the dyes, from the strong variations in the devices (with and without anti-reflection coating) and/or from the methods used for the quantification of the results (choice of the illuminating spectra, accurate evaluation of the reflectance...). Among complete studies under AM1.5G illumination,[64]'[75] Lumogen ${ }^{{ }^{-}} \mathrm{F}$ dyes (Figure 4) in EVA gave one of greatest improvement, with a relative increase of $\Delta \eta$ $=2.73 \%$ ( $\eta=14.26 \%)$, of which the LDS contribution has been estimated to $1.96 \%$.[64]

Silicon nanocrystals (Si.nc) are other promising photon converters for application to Si solar cells since they display a broad absorption in the region of interest at $400 \mathrm{~nm}$ and emit light in the 600 to $800 \mathrm{~nm}$ region and as an example, Švrček et al have calculated that the absolute efficiency of $c . \mathrm{Si}$ cells coated with a silica layer of silicon nanocrystals with $\varnothing<10 \mathrm{~nm}$ is increased by ca $0.4 \%$.[41]

Rare-earths doped encapsulants have also led to sizeable improvements in the field. Although initial studies were limited by the use of free lanthanide ions with low absorption coefficients,[76] this problem was later circumvented by incorporating $\mathrm{Eu}^{\prime \prime \prime}$ coordination complexes or $\mathrm{Eu}^{\text {"I }}$ or $\mathrm{Eu}^{\text {III }}$ phosphores such as $\mathrm{BaSiO}_{4}$ :Eu" [77] or $\mathrm{Gd}_{2} \mathrm{O}_{2} \mathrm{~S}$ :Eu"II in the LDS sheet,[78] the later leading to an increase in short-current density by $6.74 \mathrm{~mA} / \mathrm{cm}^{2}$, which corresponds of a $+2.76 \%$ relative increase in power conversion efficiency on polycrystalline silicon solar cell.

One of the first example of the use of Eu"l coordination complexes for LDS materials was reported by Fukuda et al, where they used [Eu(tta) ${ }_{3}$ phen] (Table 2) doped encapsulants (PVA, silica glasses or acryl resins) on c-Si PV modules.[62] Three years later, a nice comparative study has been published by Liu et al[79] and since then, a dozen of Eu"l ternary complexes with $\beta$-diketonate ligands have been studied.[59]'[80]'[81]'[82]'[83] The structures of the main lanthanide coordination complexes used as LDS materials in $c$-Si solar cells or $c$-Si PV module together with the relative short-circuit $\left(\Delta \mathrm{J}_{\mathrm{sc}}\right)$ and efficiency enhancement $(\Delta \eta)$ measured in the tested devices can be found in the following articles.[7] $]^{59}$

A recent example of such LSD material was obtained by spin coating a c-Si cell substrate with two concentrations of $\left[\mathrm{Eu}(\mathrm{tta})_{3}(\mathrm{tppo})_{2}\right]$ in EVA (1.3 wt\% and $2.7 \mathrm{wt} \%$, respectively). With a quantum yield of $60 \%$ in these conditions and a broad absorption up to $400 \mathrm{~nm}$, [Eu(tta) $)_{3}(\mathrm{tppo})_{2}$ ] led to an absolute increase of 19\% in EQE at short wavelengths (Figure 5).[59] 


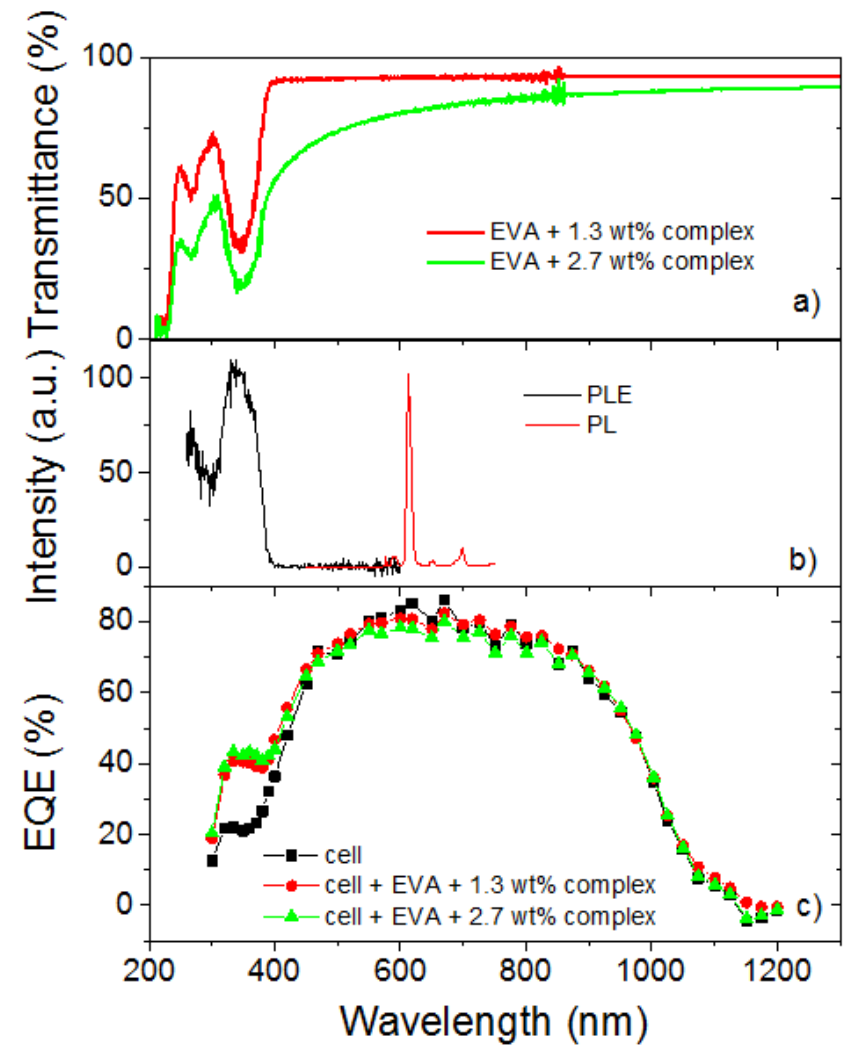

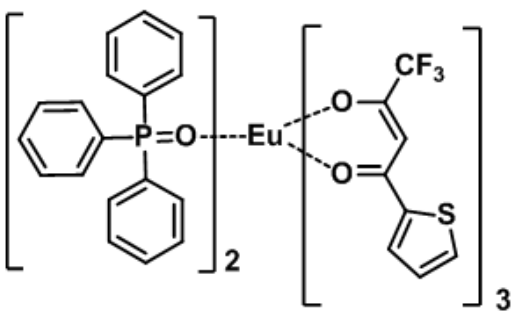

$\left[\mathrm{Eu}(\mathrm{tta})_{3}(\mathrm{tppo})_{2}\right]$

Figure 5: (a) Transmittance spectra of the quartz substrate, ethylene-vinyl acetate (EVA)-coated quartz, and EVA with two different concentrations of [Eu(tta) $)_{3}$ phen] complex. (b) PL (excitation at $350 \mathrm{~nm}$ ) and PLE (detection at $610 \mathrm{~nm}$ ) spectra of EVA with the [Eu(tta) $)_{3}$ phen] complex on quartz substrate. (c) EQE of a cSi solar cell, a cell coated with EVA, and two cells with different concentrations of [Eu(tta) ${ }_{3}$ phen] complex in EVA. Reproduced with permission from ref [59]. T. Fix, A. Nonat, D. Imbert, S. Di Pietro, M. Mazzanti, A. Slaoui, L.J. Charbonniere, Prog. Photovolt. 24 (2016) $1251-1260$.

Finally, several studies have used QDs as photon converter in the LDS layer. Recent advances in this field are described in the review of McKenna and Evans. [9] As a figure of merit, core-shell $\mathrm{Zn}_{\mathrm{x}} \mathrm{Cd}_{1}$. ${ }_{x} \mathrm{~S}: \mathrm{Mn} / \mathrm{ZnS}$ nanocrystals with PL quantum yields of $70 \%$ were obtained by Levchuk et al, using a facile and easily scalable synthesis route. When applied on top of Si cells, a relative increase of $3 \%$ in conversion efficiency, which increased from $13.8 \%$ to $14.3 \%$, was observed.[84] Very recently, slightly better results ( $+3.22 \%$ in conversion efficiency) have been obtained by Jalalah et al using a similar device (Figure 6).[85] In these systems, the doping with $\mathrm{Mn}^{2+}$ is the key of the PC since it is responsible for significantly larger Stokes shifts (> $200 \mathrm{~nm}$ ) than the undoped QDs, thereby limiting reabsorption. [86] 


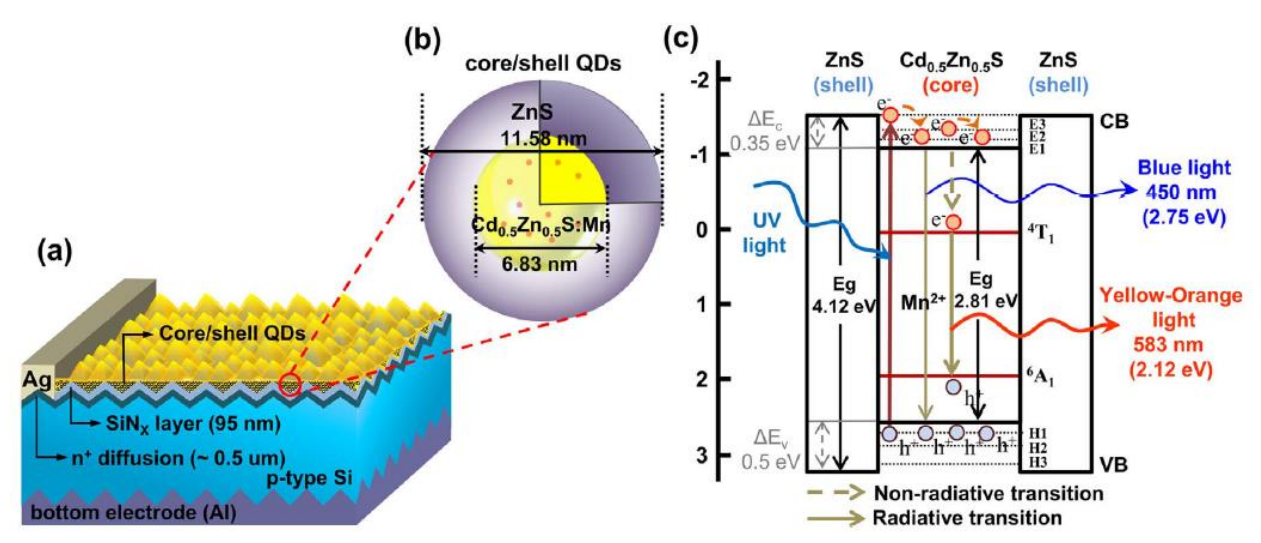

Figure 6. Schemes of an energy-down-shift having the energy-tuning effect (EDS/ETE) of $\mathrm{Mn}^{2+}: \mathrm{Cd}_{0.5} \mathrm{Zn}_{0.5} \mathrm{~S} / \mathrm{ZnS}$ QDs coated on textured pyramid-like SiNx in monocrystalline $\mathrm{p}$-type silicon (mcp-Si) solar cell. (a) Schematic structure of mc-p-Si solar cell coated with $\mathrm{Mn}^{2+}: \mathrm{Cd}_{0.5} \mathrm{Zn}_{0.5} \mathrm{~S} / \mathrm{ZnS}$ QDs layer, (b) schematic diagram, and (c) energy-band gap alignment diagram of $\mathrm{Mn}^{2+}: \mathrm{Cd}_{0.5} \mathrm{Zn}_{0.5} \mathrm{~S} / \mathrm{ZnS}$ QDs. Reproduced with permission from ref [85]. M. Jalalah, Y.-H. Ko, F.A. Harraz, M.S. Al-Assiri, J.-G. Park, Nano Energy 33 (2017) 257-265.

It is to be noticed that LDS materials are also interesting for heterojunction devices. As an example, M. Brossard, S.-Y. Kuo and H.-C. Kuo deposited graphene quantum dots at the surface of n-type Si heterojunction solar cells, which improved the absorption of photons in the depletion region, thereby improving carrier separation and hence photon conversion efficiency.[47]

\subsubsection{Thin films}

Some thin-films solar cells, such as cadmium sulfide/cadmium telluride (CdS/CdTe) or $\mathrm{ZnO} / \mathrm{CdS} / \mathrm{Cu}(\mathrm{In}, \mathrm{Ga}) \mathrm{Se}_{2}$ (CIGS) cells, also exhibit a poor spectral response at short wavelengths. In these cases, the UV and near visible photons are often absorbed by the additional window and/or buffer layers. For instance, CdS strongly absorbs photons with $\lambda<514 \mathrm{~nm}$, resulting even in narrower spectral response than silicon cells. In their first example, Hovel et al demonstrated that this parasitic absorption could be reduced with LDS materials. [69] Since, then Maruyama and Kitamura were able to increase efficiency of $\mathrm{CdS} / \mathrm{CdTe}$ solar cells from $\eta=5.0 \%$ to $\eta=6.8 \%$ (under AMD1.5 solar radiation) via the addition of Lumogen F-Dyes yellow 083 (Figure 4), a photostable organic dye with 0.91 quantum yield in chloroform,[26] to the PMMA encapsulant. The largest improvement was observed for $0.38 \mathrm{~mm}$-thick LDS layer containing $0.4 \%$ dye.[87] Above, concentration quenching does occur. To date, modern CdS/CdTe PV modules still suffer from low performances at $\lambda<540 \mathrm{~nm}$ and simple optical modelisation[74] and ray tracing analyses[88] have demonstrated that their shortwavelengths response can still be improved subsequently by addition of a LDS material such as quantum dots or dyes. Ray-tracing simulations with a 3-mm thick PMMA LDS layer containing a combination of three dyes (Lumogen Violet 570, Yellow 083, Orange 240, and Red 300, Figure 4) could lead to a relative increase in the conversion efficiency of nearly $17 \%$, possibly without making any alterations to the solar cell itself. These results have been confirmed experimentally by the study carried out by Danos and coworkers.[89] Despite their high absorption coefficients, a combination of two to three dyes is required to achieve wideband absorption in the region of interest. Such strategy was experimented by Richards and coworkers on a CdS/CdTe mini-module and leads up to $9 \%$ 
relative enhancement of the short circuit current density.[90] The influence of QDs has been investigated experimentally by Hodgson et al,[91] by depositing via doctor blading a PMMA film doped with $\mathrm{CdS}_{x} \mathrm{Se}_{1-x} / \mathrm{CdS} / \mathrm{ZnS}$ QDs with maximum emission at $490 \mathrm{~m}(\Phi=62 \%)$ on $\mathrm{Cd}_{1-\mathrm{x}} \mathrm{Zn}_{\mathrm{x}} / \mathrm{CdTe}$ cells. First results were not satisfactory because, despite an increase of the EQE from $4 \%$ to $20 \%$ at short wavelengths, an overall reduction of the short current density was measured due to important losses by re-absorption and scattering.[91] After optimization of the QDs concentration within the films, an overall improvement of $1.7 \%$ was finally achieved.[92]

In $\mathrm{ZnO} / \mathrm{CdS} / \mathrm{CIGS}$ cells, both $\mathrm{CdS}$ and $\mathrm{ZnO}$ (which absorbs photons $\lambda<350 \mathrm{~nm}$ ) are involved. By using a combination of fluorescent Lumogen ${ }^{\circledR} \mathrm{F}$ dyes Violet 570 and Yellow 083), Glaeser et al were able to improve the absolute conversion efficiency by $\Delta \eta=0.8 \%$ (absolute, based on $\eta=14 \%$ without coating).[93] It was estimated that $0.53 \%$ were due to photon downshifting and $0.27 \%$ to reduced overall reflectance. Similar strategy was later used by Klampaftis et al[27] and also by Solodovnyk et al,[94] showing up to $2.93 \%$ relative increase in photon conversion efficiency,[95] however, longterm photostability of the dyes still prevents the utilization of this technology for production purposes.[27]

Eu(III) coordination complexes are another promising luminophores for LDS materials on CIGS solar cells because they possess strong red emission and high photostability. We have compared the luminescence properties and photon conversion efficiency of 13 ternary Eu'I' complexes, deposited on the top of CIGS cells, either by spin coating of polymeric films (EVA, PMMA or PVB) doped with these complexes,[96] or when applied as nanometric $(150-6000 \mathrm{~nm})$ layers.[61] In all cases, very strong photoluminescence have been observed upon excitation at $340 \mathrm{~nm}$, achieving quantum yields above $80 \%$ (and up to $86 \%$ for [ $\mathrm{Eu}(\mathrm{nta})_{3}\left(\mathrm{tppo}_{2}\right.$ ] in PMMA, Table 2). This resulted in significant improvements of the external quantum efficiency (EQE) in the UV region, which reached up to $59 \%$ at $350 \mathrm{~nm}$ compared to $5 \%$ for the original cell (Figure 7), and to a $0.8 \%$ absolute increase in conversion efficiency.[96],[61]

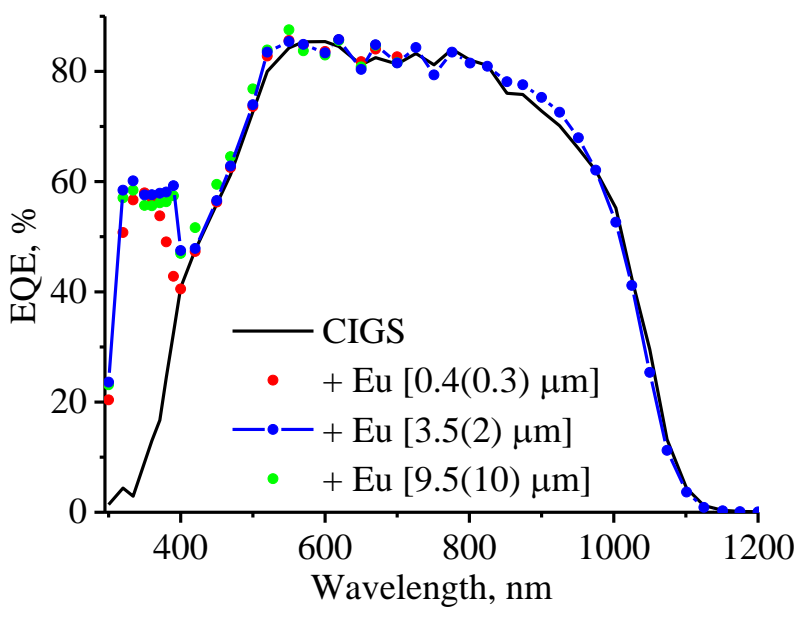

Figure 7. EQE spectra of CIGS solar cells covered with nanolayers of $\left[\mathrm{Eu}(\mathrm{tta})_{3}(\mathrm{tppo})\right]$ at different thicknesses. Reproduced with permission from ref [61]. A. Gavriluta, T. Fix, A. Nonat, A. Slaoui, J.-F. Guillemoles, L. Charbonnière, Eur. J. Inorg. Chem. 44 (2017) 5318.

Several examples of internal LDS layer, such as Nd-doped $\mathrm{SnO}_{2}$ films[97] or CdSe/ZnS QDs, [47] have also been reported with CIGS cells. In such cases, enhancement is observed at short wavelength due 
to luminescent down-shifting (LDS) as well as at longer wavelengths because of internal scattering and more efficient energy transfer.

\subsubsection{Hybrid perovskite}

Perovskite are organic-inorganic materials with limited thermal and UV resistance. However, several studies have shown that their long-term stability could be improved by implementing LDS layers. Interestingly, three different strategies have been reported to date.[5],[98],[99] In their first study, A.F. Khan et al used $\mathrm{Y}_{1-\mathrm{x}} \mathrm{VO}_{4}: \mathrm{Eu}_{\mathrm{x}}(\mathrm{x}=0.05-0.13)$ nanoparticles, which they deposited by spray coating of a solution in propanol on the reverse FTO glass (Figure 8).[98] In a different approach, $\mathrm{X}$. Chen, $\mathrm{H}$. $\mathrm{Li}$ and $\mathrm{L}$. Pan used $\mathrm{ZnGa}_{2} \mathrm{O}_{4}:$ Eu nanoparticles which they incorporated by spin coating into a mesoporous $\mathrm{TiO}_{2}$ layer.[99] This strategy does not affect the crystallization of $\mathrm{CH}_{3} \mathrm{NH}_{3} \mathrm{Pbl}_{3}$ and offers the advantage of minimum light scattering. Finally, F. Bella and G. Griffini obtained the best results in aging tests (up to 180 days under various stresses) and a stability of more than 3 months under real outdoor conditions by implementing fluoropolymeric coating on both sides of the cells. [5] Because of its strong hydrophobic character, the polymer coating acts as a moisture barrier. Moreover, at the glass-side, the polymer was doped with Lumogen F Violet (Figure 4), which converts UV photons in the $320-400 \mathrm{~nm}$ region at $c a .450 \mathrm{~nm}$, where the device is the most efficient. In all cases, improved stability for coated over uncoated devices was observed together with sensible improvements of their photon conversion efficiency.

a)

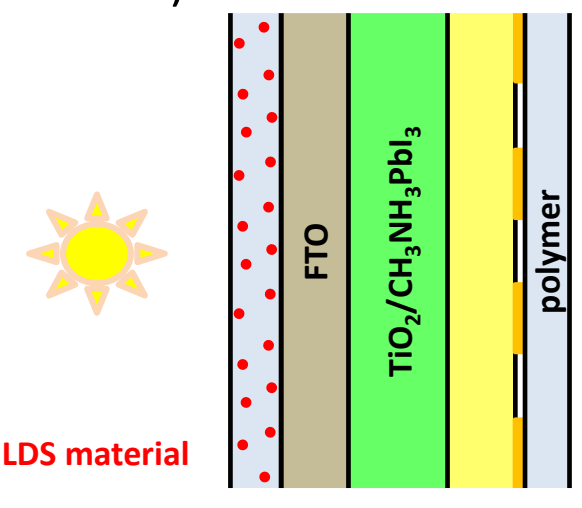

b)

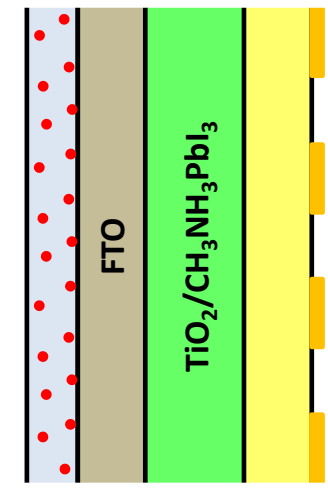

c)

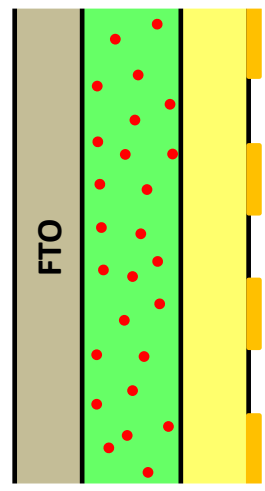

Figure 8. Schematic representation of perovskite cell structures with LDS layers: on the reverse of FTO glass with (a) and without (b) polymer coating at the back side; in $\mathrm{TiO}_{2}$ layer (c).

\subsubsection{Organic photovoltaic devices and dye-sensitized solar cells}

Very recent studies on the use of LDS layers on organic photovoltaic devices (OPV) and dye-sensitized solar cells (DSSC) have been published. Similarly to the perovskite technology, the role of the LDS layer here is no only to improve UV-light harvesting efficiency but also to improve the stability of the device by inhibiting UV degradation of the dye sensitizer. Lanthanide-based luminophores, which provide the advantage of stong photostability, look particularly interesting. As an example, a $1 \mu \mathrm{m}$ LDS layer of the [Eu(hfa) $)_{3}$ (phen)] complex (Table 2) in PMMA, deposited by doctor blading, led to an increase of $+850 \%$ of the half-life of the OPV together with a small enhancement in photocurrent $(+5 \%) \cdot[100]$ 


\subsection{Downconversion}

The first experimental demonstration of downconversion for solar cells, in 2005, involved $\left(\mathrm{Yb}_{\mathrm{x}} \mathrm{Y}_{1-\mathrm{x}}\right) \mathrm{PO}_{4}$ crystals doped with $1 \% \mathrm{~Tb}^{\mathrm{II \prime}}$.[101] In this system, quantum cutting was achieved through cooperative energy transfer from $\mathrm{Tb}^{\text {III }}$ to two $\mathrm{Yb}^{\mathrm{III}}$ ions. Other down-converters couples such as $\mathrm{Tm}^{\mathrm{III}}-$

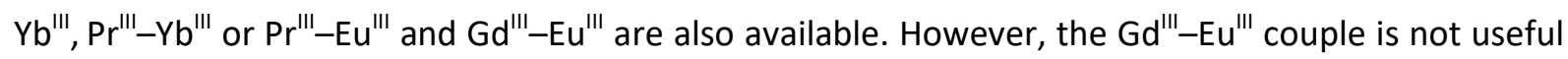
for improving solar cell efficiency, since excitation wavelengths involved $(<200 \mathrm{~nm})[102]$ are not present in the solar spectrum.

$\mathrm{Ce}^{\mathrm{III}}$ is also being used as a donor since it provides the advantage of a larger absorption cross section. [103]'[104]'[105]'[106]

For this application, UV/Vis (absorption in the $350-550 \mathrm{~nm}$ region) to VIS or NIR (emission in the 550 - $1100 \mathrm{~nm}$ range) quantum cutting systems have to be used.[107] Such systems have been reported in the literature and consist mostly in inorganic materials such as silicon nanocrystals, [108] tellurite glasses, $\mathrm{GdAl}_{3}\left(\mathrm{BO}_{3}\right)_{4}, \mathrm{Gd}_{2} \mathrm{O}_{2} \mathrm{~S},[109] \mathrm{GdBO}_{3}$ or $\mathrm{YBO}_{3},[104] \quad \mathrm{Y}_{2} \mathrm{O}_{3}, \mathrm{YPO}_{4}, \mathrm{YVO}_{4},[110] \quad \mathrm{NaYF}_{4},[106]$ $\mathrm{CaF}_{2}$ [103]'[105]'[111] and $\mathrm{LaF}_{3}[112]$ nanocrystals and glasses[113] co-doped with Ce', $\mathrm{Tb}^{\prime \prime \prime}, \mathrm{Pr}^{\prime \prime \prime \prime}, \mathrm{Er}^{\mathrm{II \prime}}$ or $\mathrm{Tm}^{\prime \prime \prime}$ and $\mathrm{Yb}^{\mathrm{III}}$. Further details concerning the energy transfer mechanisms for the various rare earth ion pairs can be found in the review by J. Lin et al.[114] As a figure of merit, an optimal quantum efficiency close to $200 \%$ has been observed in $\mathrm{GeO}_{2}-\mathrm{B}_{2} \mathrm{O}_{3}-\mathrm{ZnO}-\mathrm{LaF}_{3}$ glasses by using $\mathrm{Pr}^{\prime \prime \prime}$, $\mathrm{Tb}^{\prime \prime \prime}$, and $\mathrm{Tm}^{\prime \prime \prime}$ as donors $\left(\mathrm{Ln}_{\mathrm{D}}\right)$ and $\mathrm{Yb}^{\prime \prime \prime}$ as acceptor $\left(\mathrm{Ln}_{\mathrm{A}}\right)$. [112] In the case of such high quantum efficiencies, theoretical studies predict a maximum conversion efficiency of $39.63 \%$ when using a downconverting material at the top of a c-Si cell.[115] However in practice, results in the absolute efficiencies of PV systems with down-converters are low (<0.1\%).[116]'[117]'[118]'[76] This is due to the low absorption cross section of the downconverters developed to date and in some cases, to adverse light scattering. Moreover, it is to be enlightened that the quantification of such energy transfers is not an easy task and it is very difficult to discriminate between downconversion (two photons) and downshifting (one photon) mechanisms with currently available experimental set-ups. The reader is invited to be critical with literature reports to this respect since the word "downconversion" is from time to time used to describe one photon processes. Two methods are currently used to quantify the efficiency of downconversion. The first method was described by P. Vergeer et al[101] and relies on a cooperative dipole-dipole interaction between the donor and the acceptor. This method allows determining the efficiency of the energy transfer process based on the measurements of the excited states lifetimes of the donor in presence (and in absence of the acceptor). Since it does not take into account the quantum yield of the acceptor (which is particularly important for NIR emitters with lower quantum yields and for strong concentration quenching in case of high doping levels) nor the sensitization the photosensitization efficiency of the donor, this method cannot be used to measure quantum efficiencies of downconversion. More recently, integrating spheres have been used to calculate the quantum yield of the $\mathrm{Yb}^{\mathrm{II}}$ ion by an absolute method. For lower quantum yields, this method does not allow to distinguish between the two mechanisms; however, in the case of PLQY $>100 \%$, it is surmised that quantum-cutting occurs. One should keep in mind that experimental errors are estimated to $15 \%$.

As an example, W. Xu and H. Song have measured a quantum yield of $119 \%$ for $\mathrm{Yb}^{\prime \prime \prime}$ in $\mathrm{Yb}^{\prime \prime \prime}, \mathrm{Ce} \mathrm{e}^{\mathrm{II \prime}}$ co- 
doped perovskite halide nanocrystals ( $\left.\mathrm{CsPbCl}_{1.5} \mathrm{Br}_{1.5}: \mathrm{Yb}^{\prime \prime \prime}(7.1 \%): \mathrm{Ce}^{\prime \prime \prime}(2 \%)\right)$, upon excitation in the perovskite at $365 \mathrm{~nm}$.[119] An overall quantum yield of $146 \%$ has been measured, which is the highest quantum yield reported to date for downconverters. As a comparison, $\mathrm{CsPbCl}_{1.5} \mathrm{Br}_{1.5}$ : $\mathrm{Ce}^{\text {III }}(2 \%)$ have also be studied. From the PLQY of $94 \%$ in the NIR in absence of $\mathrm{Ce}^{\mathrm{III}}$, we can assume a quantumcutting efficiency around $13 \%$. The absorption and emission spectra, as well as the schematic diagram of energy transfer processes are presented in Figure 9. When applied the top of silicon solar cells, a relative enhancement of photon conversion efficiency of $18.8 \%$ was obtained.
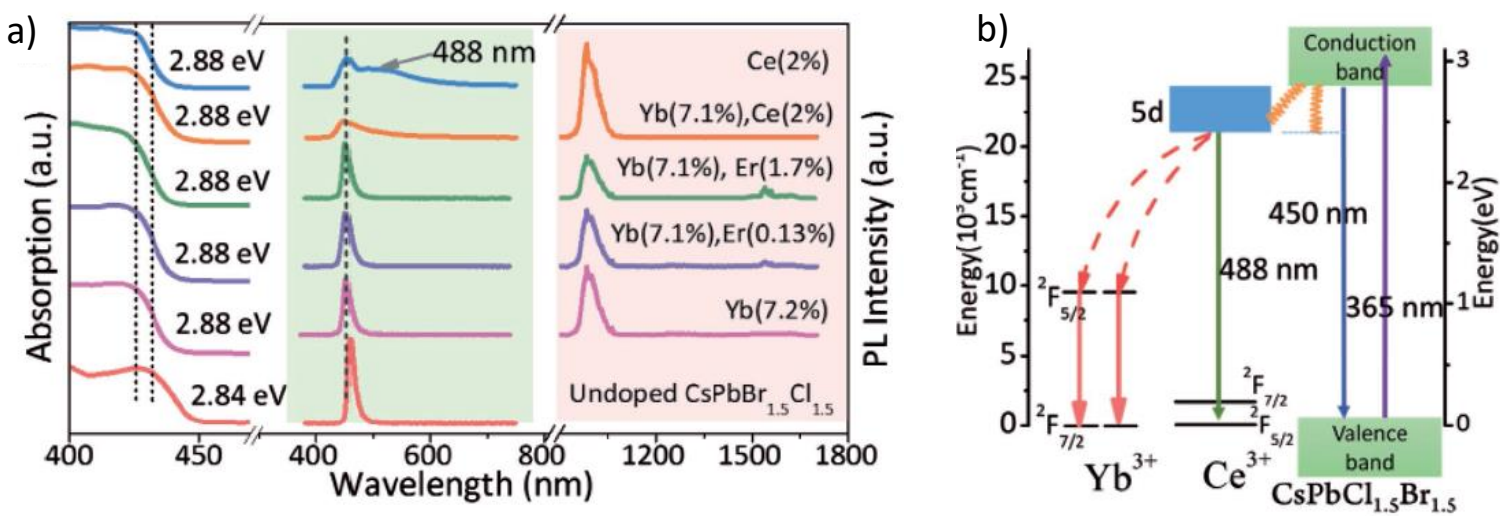

Figure 9. a) Absorption spectra (left), visible emission spectra (middle), and near-infrared emission spectra (right, excited at $365 \mathrm{~nm}$ ) of $\mathrm{CsPbCl}_{1.5} \mathrm{Br}_{1.5}$ perovskite nanocrystals codoping with different $\mathrm{RE}$ ions. b) Schematic diagram of energy transfer mechanism in the nanocrystals. Reproduced with permission from ref [119]. D. Zhou, D. Liu, G. Pan, X. Chen, D. Li, W. Xu, X. Bai, H. Song, Adv. Mater. 29 (2017) 1704149.

A very interesting and detailed spectroscopic study has been reported by Q-Y. Zhong and A. Meijerink, in which they were able to study and quantify quantum-cutting processes in $\mathrm{Gd}_{2} \mathrm{O}_{2} \mathrm{~S}$ doped

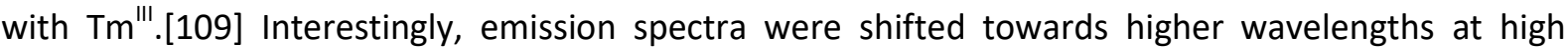
doping levels, as a consequence of cross-relaxation processes in which NIR photons from the ${ }^{3} \mathrm{H}_{4}$ level of $\mathrm{Tm}^{\mathrm{III}}$ are converted into 2 NIR photons of lower energy $(1800 \mathrm{~nm})$, visible photon from the ${ }^{1} \mathrm{G}_{4}$ excited state in 3 photons and UV photons at $365 \mathrm{~nm}$ from the ${ }^{1} \mathrm{D}_{4}$ in 4 NIR photons. A model of cross-relaxation based on dipole-dipole interaction is proposed, allowing calculation of downconversion efficiencies of $300 \%, 300 \%$ and $400 \%$, respectively.

Whereas most studies have been performed with silicon solar cells, recent advances in the fields have also shown a good potential when using LDS materials on DSSC solar cells.[6],[120]

In conclusion, in addition to fundamental aspects on the theoretical study of energy transfer mechanisms, two key points need to be addressed for future applications with downconverting layers, which are: (i) optimizing sensitization and (ii) reducing losses arising from concentration quenching of $\mathrm{Yb}^{\mathrm{III}}$

\section{Upconversion}

\subsection{Principle}


Upconversion is an anti-Stokes phenomenon, in which emission occurs at higher energy than the excitation. This phenomenon was first mentioned in 1959-1960 [121,122] when investigating lanthanide doped materials for the development of infrared detectors. Since then, a large variety of applications can be found such as in bioimaging, lasers and photovoltaics. It was applied to solar cells first in a GaAs solar cell in 1996 [123]. The vitroceramic developed, doped with $\mathrm{Yb}^{3+}$ and $\mathrm{Er}^{3+}$, provided $2.5 \%$ efficiency under high excitation densities. A comprehensive review of upconverter materials and their efficiency can be found in [124,125].

\subsection{Mechanisms}

The upconversion processes can be classified into three categories: the excited-state absorption, the energy transfer upconversion and the photon avalanche [125]. In the excited-state absorption, an incoming photon creates a transition from a ground level $\mathrm{G}$ to an excited level E1 as described in Figure 10. In the energy transfer upconversion, one ion is already in an excited level E1 but there is an energy transfer from a second ion in an excited level $\mathrm{E} 1$ to the first ion, so that the first ion ends in an excited level E2 [125]. In general with upconversion system the level E1 is in the middle of the G and E2 levels. Photon avalanche involves the cross-relaxation of one ion in the E2 level to a neighboring ion in the ground state, and the transfer of the neighboring ion now in a E1 level enables the transfer of the first ion from the E1 to the E2 level. This avalanche system allows an increase of upconversion efficiency. Because all these phenomena require transfer between ions, the distance between two emitting ions is paramount for high upconversion efficiency. Therefore in most studies the concentration of the emitting ions is optimized. When the concentration of these ions, which is typically around a few \%, becomes too high, quenching effects appear and reduce the amount of photoluminescence. One of the reasons for the low quantum yield observed in upconversion is the fact that these emitting ions at low concentration do not absorb light sufficiently.

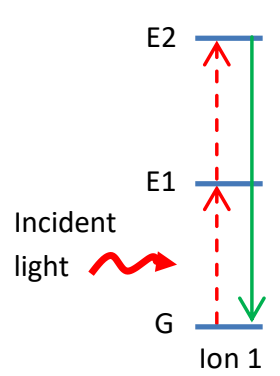

Excited-state absorption

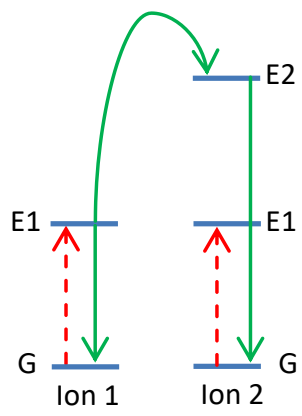

Energy transfer upconversion

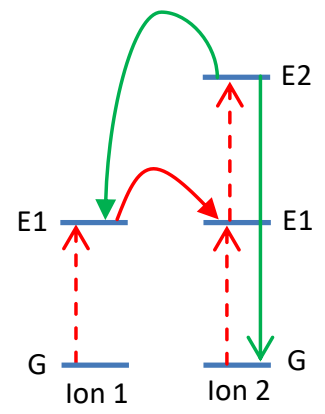

Photon avalanche

Figure 10: Schematics of three upconversion processes.

The number of photons upconverted obeys to a power law dependence in the form of $P^{n}$ where $P$ is the incoming light intensity and the number of photons needed to excite the upconverted state. This means that the photogenerated short-circuit current in a solar cell integrating an upconverter will 
follow the same power law. Therefore, upconversion in solar cells is mostly efficient at higher light concentration.

\subsection{Upconversion for solar cells}

Upconversion converts two or more photons with low energy into one photon of energy that can be used by the solar cell. In a solar cell, this principle enables to reduce the losses due to the fact that photons with energy lower than the bandgap are not absorbed by the semiconductor of the solar cell. Together with thermalisation losses (excess energy dissipated as heat), these losses are referred to spectral mismatch losses. They account for $70 \%$ of the energy losses in a single bandgap solar cell. Multijunctions are one solution to reduce these losses, however their fabrication is more complex than standard solar cells.

While in downconversion the active converter must be placed on top of the solar cell, because it absorbs photons of higher energy than the bandgap of the active converter, in upconversion it could be placed either on top or underneath the solar cell. It is advantageous for upconversion to place it underneath the solar cell, so that the functioning of the solar cell is not altered (Figure 11). Moreover, Badescu et al. have shown that placing the upconverter on top of the solar cell is disadvantageous [126].

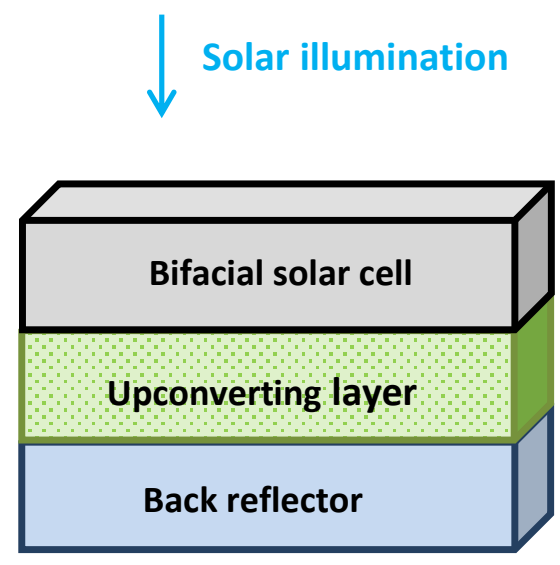

Figure 11: Schematics of the position of the upconverting layer combined with a bifacial solar cell.

Balance calculations on the theoretical efficiency limit of a solar cell combined with an upconverter were performed by Trupke et al. [127]. For this they introduced a bifacial single junction solar cell with an upconverter located on one of the faces, followed by a reflector. Then they used the approach of Shockley and Queisser and the Kirchhoff's law to calculate an equivalent circuit of the up-conversion system. They found that the maximum efficiency for a bandgap of the solar cell of 1.1 $\mathrm{eV}$ is about 55\%. Another calculation by Johnson et al. for c-Si solar cells with a bandgap of $1.1 \mathrm{eV}$ used a realistic c-Si absorption spectrum and showed that the limiting efficiency of the solar cell could increase from $33 \%$ to $40 \%$ with ideal upconversion [128].

The main limiting factor for the introduction of upconversion in industrial solar cells is the low efficiency of the upconversion process. Upconversion is a non-linear process which means that higher efficiency of the conversion process can be found for concentrated light. The upconversion 
luminescence varies linearly with the irradiance above a certain irradiance threshold. Therefore, proposed experimental set-ups are often based on solar cells with concentrators.

In order to compare the different upconversion materials, the internal upconversion quantum yield is defined as the ratio of the photon flux of upconverted photons to the photon flux absorbed by the upconverter. As proposed in [124], the external upconversion quantum yield is obtained by multiplying the internal upconversion quantum yield with the absorptance of the upconverter.

These quantum yields are typically measured in integration spheres using monochromators. The external quantum efficiency of solar cells integrating an upconverter can also be measured to compare the efficiency of different upconverters. The amount of extra short-circuit current with or without upconverter can also be measured in a solar simulator, howvever spectral mismatch corrections need to be introduced.

\subsection{Upconversion materials}

There are two main kinds of upconverting materials, the ones based on lanthanide or transition metal ions and the ones that are organic. The former involve an inorganic host into which the lanthanide or transition metal elements are added. Some upconverting materials can also be qualified as hybrid because they are based on coordination complexes involving lanthanide ions [129].

17 elements compose the rare-earth family. 15 of these 17 elements belong to the group of lanthanides from $L a$ to $L u$, the remaining two being $Y$ and Sc. The trivalent lanthanide ions have an electron configuration in the form of $4 f^{n} 5 s^{2} 5 p^{6}(0<n<14)$. The useful optical transitions of lanthanides are based on the $4 \mathrm{f}$ shell and are relatively independent of the host material, as far as their energetic position is concerned, which is due to the shielding of the $4 f$ electrons by the complete $5 s$ and $5 p$ shells. Therefore their transitions are often represented by the Dieke diagram. However, the broadness and intensity of the absorption spectrum varies from host to host, which will influence the upconversion quantum yield.

Common hosts are $\mathrm{NaYF}_{4}, \mathrm{NaGdF}_{4}, \mathrm{BaYF}_{5}$ and $\mathrm{Y}_{2} \mathrm{O}_{3}$ [125] and common dopants are $\mathrm{Er}^{3+}, \mathrm{Tm}^{3+}$, and $\mathrm{Ho}^{3+}$ as emitter and $\mathrm{Yb}^{3+}$ as sensitizer. $\mathrm{Yb}^{3+}$ is often used to play the role of the absorber in upconversion systems because of its large absorption cross-section in the near infrared. The choice of the host matrix determines the distance between the emitting ions, and therefore influences the upconversion efficiency, as well as the nature of the atoms surrounding the lanthanides. The host material is required to provide low lattice phonon energy and must enable the insertion of the dopant ions in the lattice.

The internal upconversion quantum yield rarely exceeds $10-15 \%$ in the bulk. Upconverter nanomaterials do not generally exceed $2 \%$ in quantum yield, which is attributed to surface quenching [124]. The most efficient systems include micro on mono-crystalline $\beta-\mathrm{NaYF}_{4}: 20 \% \mathrm{Er}^{3+}[130,131]$, $\mathrm{Gd}_{2} \mathrm{O}_{2} \mathrm{~S}: 10 \% \mathrm{Er}$ [132], and $\mathrm{BaY}_{2} \mathrm{~F}_{8} 30 \% \mathrm{Er}$ [133]. However it should be noted that most of these values are obtained under monochromatic excitation and therefore do not reflect the efficiency of such materials under a solar spectrum. Upon excitation at around $1500 \mathrm{~nm}$, the $\mathrm{Er}^{3+}$ ion emits by upconversion in four bands : ${ }^{4} I_{11 / 2}{ }^{4} I_{15 / 2}$ at $980 \mathrm{~nm},{ }^{4} I_{9 / 2}{ }^{4} I_{15 / 2}$ at $810 \mathrm{~nm},{ }^{4} \mathrm{~F}_{9 / 2^{-}}{ }^{4} I_{15 / 2}$ at $600 \mathrm{~nm}$ and ${ }^{4} S_{3 / 2^{-}}$ 
${ }^{4} I_{15 / 2}$ at $550 \mathrm{~nm}$. It was shown that the upconversion mechanism depends on the light intensity. At low light intensity, the dominating upconversion mechanism is two-step $\left({ }^{4} I_{15 / 2}{ }^{4} I_{13 / 2}{ }^{4} I_{11 / 2}\right)$ while at higher intensity it is three-step $\left({ }^{4} \mathrm{I}_{15 / 2}-{ }^{4} \mathrm{I}_{13 / 2}-{ }^{4} \mathrm{I}_{11 / 2}{ }^{4} \mathrm{~S}_{3 / 2}\right)[133]$.

$\mathrm{Er}^{3+}$ is often combined with $\mathrm{Yb}^{3+}$ where $\mathrm{Yb}^{3+}$ absorbs two photons at around $980 \mathrm{~nm}$ as a sensitizer and transfers this energy to $\mathrm{Er}^{3+}$ that provides upconversion luminescence around 550 and $650 \mathrm{~nm}$ $[125,135]$. $\mathrm{Er}^{3+}$ has an energy level $\left({ }^{4} \mathrm{I}_{11 / 2}\right)$ that can be populated by energy transfer from $\mathrm{Yb}^{3+}$ (Figure 12). $\mathrm{Ho}^{3+}$-doped oxyfluoride or fluorindate glasses have also been proposed, where upon excitation at $1170 \mathrm{~nm}, \mathrm{Ho}^{3+}$ emits by upconversion in two bands, ${ }^{5} \mathrm{~F}_{5}{ }^{5} \mathrm{I}_{8}$ at $650 \mathrm{~nm}$ and ${ }^{5} \mathrm{I}_{5}{ }^{-5} \mathrm{I}_{8}$ at $910 \mathrm{~nm}$.

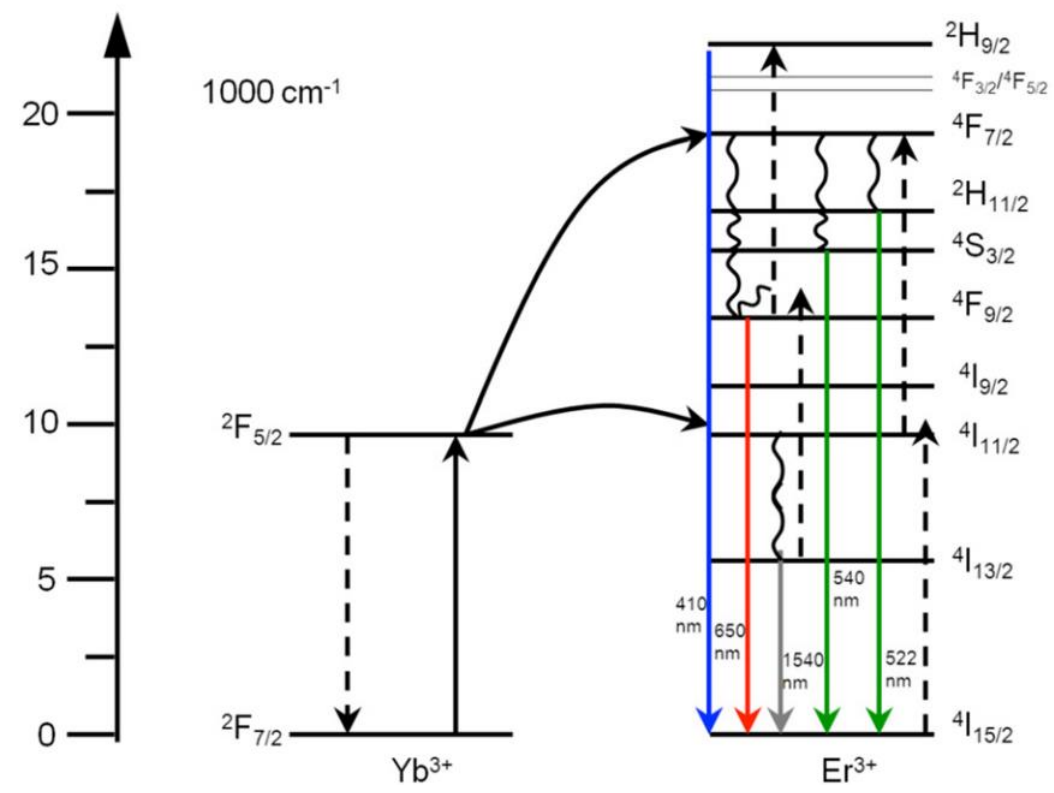

Figure 12: Upconversion in the $\mathrm{Yb}^{3+}, \mathrm{Er}^{3+}$ couple, showing that a two-step transfer enables the excitation of $\mathrm{Er}^{3+}$ in the ${ }^{4} \mathrm{~F}_{7 / 2}$ state and relaxation by emission in the blue, green, red of infrared Reproduced with permission from [136]. W. G. J. H. M. van Sark, J. de Wild, J. K. Rath, A. Meijerink and R. E. Schropp, Nanoscale Research Letters 2013, 8, 81

There are also examples of upconverters with glass ceramics, with a quantum yield of $12.7 \%$ in $\mathrm{Er}^{3+}$ doped ZBLAN [137].

As for organic compounds, they are often based on triplet-triplet annihilation (TTA) compounds. The process is basically similar to the inorganic materials, with absorption, transfer and emission. Most efficient examples are PT(II) complex/DPA [138] and PtOEP/DPA [139]. Many examples of such upconverters are only found in solutions, which is impractical for application in photovoltaics. However they are often embedded into polymers such as PMMA which can play the role of the encapsulant [140].

\subsection{Devices}


Most upconverting solar cell devices are based on bifacial solar cells as in Figure 13. The rear side of the solar cell plays the role of recovering the light photoemitted by the upconverter and does not see direct solar illumination.

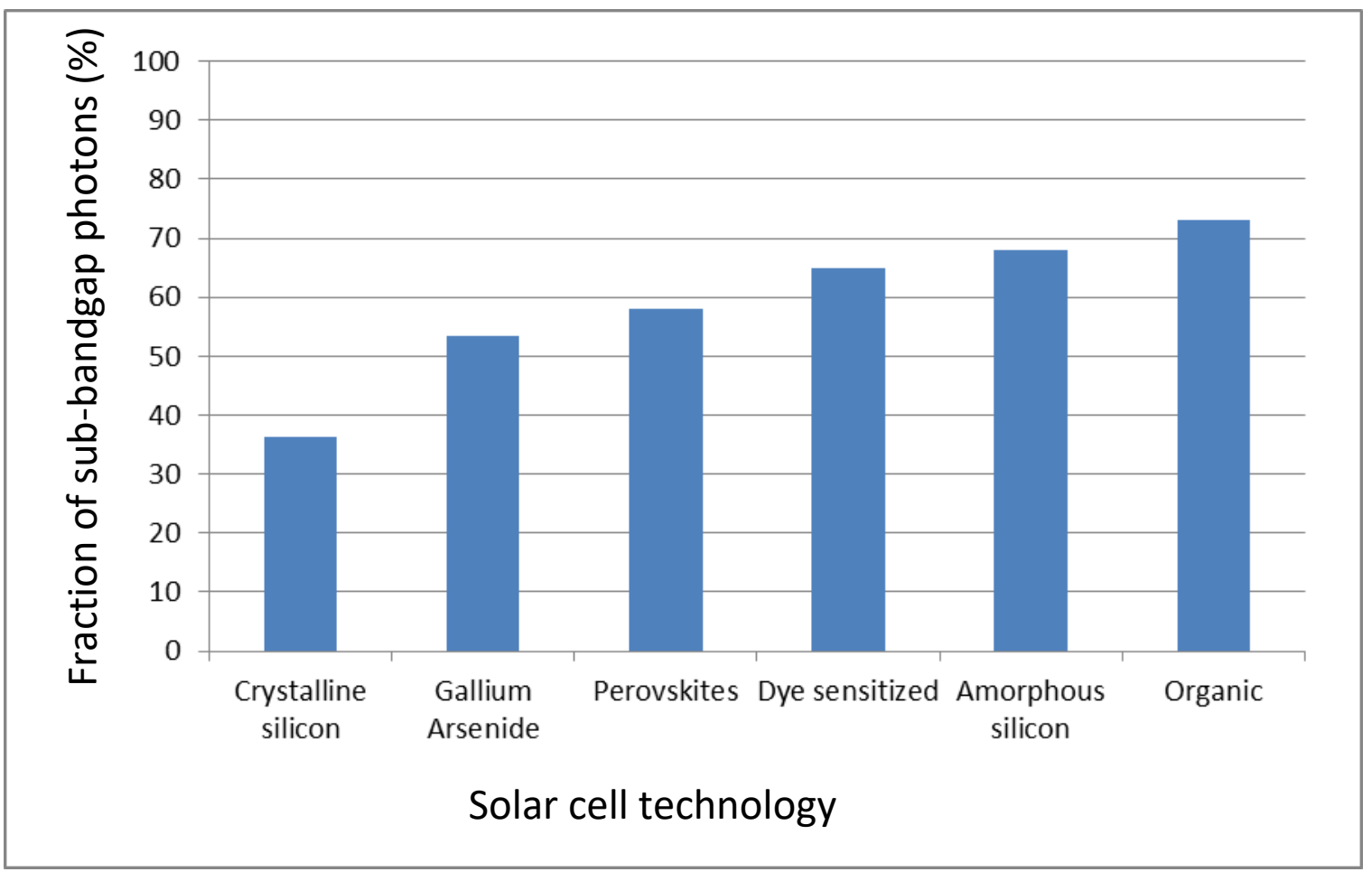

Figure 13: Fraction of photons below the bandgap that is not exploited by each technology and could be recovered by upconversion.

\subsubsection{Crystalline silicon solar cells}

There were several attempts to integrate upconverters in crystalline silicon solar cells. It has been shown that for crystalline silicon the potential relative gain in conversion efficiency thanks to upconversion is 35\% [141]. Many examples are based on $\beta-\mathrm{NaYF}_{4}: \mathrm{Er}^{3+}[130,142]$. Using $\beta$-NaYF4:25\% $\mathrm{Er}^{3+}$ in bifacial crystalline silicon solar cells, an EQE originating from upconversion of $1.79 \%$ was found under monochromatic excitation of $1508 \mathrm{~nm}$ with an irradiance of $0.1 \mathrm{~W} / \mathrm{cm}^{2}$ [143]. The $\left(\mathrm{Yb}^{3+}, \mathrm{Er}^{3+}\right)$ couple is not convenient for silicon solar cells because the $\mathrm{Yb}^{3+}$ ion has only excited state ${ }^{2} \mathrm{~F}_{5 / 2}$ at $980 \mathrm{~nm}$ which corresponds to a wavelength where $\mathrm{Si}$ solar cells are still effective.

In another example microsized $\mathrm{NaYF}_{4}: 20 \% \mathrm{Er}^{3+}$ phosphors were mixed in an acrylic adhesive medium and deposited on the rear of a bifacial solar cell. An EQE of $2.5 \%$ was obtained under excitation at $1523 \mathrm{~nm}[134]$.

Other examples on silicon solar cells include $\mathrm{Gd}_{2} \mathrm{O}_{2} \mathrm{~S}: 10 \% \mathrm{Er}^{3+}$ with $4.74 \%$ EQE [124], and $\mathrm{BaY}_{2} \mathrm{~F}_{8}: 30 \% \mathrm{Er}^{3+}$ with $3.6 \% \mathrm{EQE}$ [133], both at $1511 \mathrm{~nm}$ and with an irradiance of $0.1 \mathrm{~W} / \mathrm{cm}^{2}$. Another example with $\mathrm{Gd}_{2} \mathrm{O}_{2} \mathrm{~S}$ doped with $10 \% \mathrm{Er}^{3+}$ gave an internal quantum yield of $12 \%$ under excitation at $1500 \mathrm{~nm}$ with an irradiance of $0.7 \mathrm{~W} / \mathrm{cm}^{2}$ [144].

The $\mathrm{Ho}^{3+}$ is also investigated as emitter, with the advantage of harvesting light in the 1150-1230 nm range and emitting by upconversion at around $650 \mathrm{~nm}$ and $910 \mathrm{~nm}$. $\mathrm{Ho}^{3+}$ was used in upconverting 
glass ceramics placed on c-Si solar cells [145] and was combined with $\mathrm{Yb}^{3+}$ as sensitizer or with $\mathrm{Er}^{3+}$ to broaden the absorption range [146].

Concerning tests in solar simulators and not under monochromatic excitation, most studies use concentrated light where the efficiency of the upconverter is higher.

For amorphous silicon solar cells, studies focus on similar upconverters as for crystalline silicon solar cells. Due to the higher bandgap of a-Si:H solar cells $(1.75 \mathrm{eV})$, the potential gain with upconversion is higher than for c-Si. Indeed, light of wavelength above $710 \mathrm{~nm}$ are not absorbed. Examples applied to amorphous silicon solar cells include $\mathrm{NaYF}_{4}: \mathrm{Yb}^{3+}, \mathrm{Er}^{3+}$ nanoparticles [147], $\mathrm{NaYF}_{4}: \mathrm{Yb}^{3+}, \mathrm{Er}^{3+}, \mathrm{Gd}^{3+}$ nanorods [148] and $\mathrm{Gd}_{2} \mathrm{O}_{2} \mathrm{~S}: \mathrm{Yb}^{3+}, \mathrm{Er}^{3+}$ upconverters [149].

\subsubsection{DSSC solar cells}

In the very recent years, upconversion applied to dye-sensitized solar cells (DSSC) has attracted increasing attention. These solar cells are composed of a dye-sensitized TiO2 semiconductor film, an electrolyte solution based generally on a $\mathrm{I}^{-} / \mathrm{I}^{3-}$ redox couple, and transparent conductive oxide coated on glass as electrodes. The best DSSC cells do not exceed about $13 \%$ efficiency and this is partly due to the fact that the dye molecules have a bandgap generally about $1.6 \mathrm{eV}$ and therefore light above $800 \mathrm{~nm}$ is not absorbed. This makes upconversion beneficial for this type of solar cells. Indeed, dyes absorbing in the infrared are known to be poorly photostable [150]. A recent record of conversion efficiency of $14.5 \%$ has been achieved in a liquid-based DSSC [151]. However, the light harvesting efficiency is not the only limiting factor for conversion efficiency, but also the electron injection efficiency and the rate of charge recombination [152]. A review on upconversion for DSSC solar cells can be found in [152], where it is suggested that the incorporation of upconversion material into the photoanodes is also beneficial in terms of light scattering and reduction of electron-hole recombination.

Generally the upconverting material is added to the photoanode of the DSSC. Upconversion was first applied to DSSC in $\mathrm{Er}^{3+}-\mathrm{Yb}^{3+}$ doped $\mathrm{LaF}_{3}$ and combined with $\mathrm{TiO}_{2}$ [153]. Upon excitation at $980 \mathrm{~nm}$, green $(543 \mathrm{~nm})$ and red $(655 \mathrm{~nm})$ emission was observed due to $\mathrm{Er}^{3+}$ photoluminescence induced by upconversion. There are examples where to upconverting material was applicated externally to the DSSC electrode as a rear layer, such as $\beta-\mathrm{NaYF}_{4}: \mathrm{Er}^{3+}, \mathrm{Yb}^{3+}$ nanoplatelets, leading to a $10 \%$ enhancement of conversion efficiency [154].

A increase of conversion efficiency from $5.84 \%$ to $7.90 \%$ was reported using $\mathrm{YF}_{3}: \mathrm{Yb}^{3+}, \mathrm{Er}^{3+}$ in $\mathrm{TiO}_{2}$ [155]. This increase of efficiency was due to both the upconversion of $\mathrm{Yb}^{3+}, \mathrm{Er}^{3+}$ and the increase of the open circuit voltage due to a p-type doping effect of the upconverter [155]. In another study, $\mathrm{TiO}_{2}: \mathrm{Er}^{3+}$ was mixed with raw $\mathrm{TiO}_{2}$, leading to an enhancement of $62.9 \%$ in conversion efficiency. Apart from the reasons mentioned before in this paragraph, this increase of efficiency was also explained by the fact that the $\mathrm{TiO}_{2} /$ doped $\mathrm{TiO}_{2}$ mixture is a potential driver for excited electrons to inject into the inner raw $\mathrm{TiO}_{2}$ layer and it reduces recombinations [152].

Core-shell nanoparticles were proposed as photoanodes of DSSC, for example $\mathrm{NaYF}_{4}: \mathrm{Yb}^{3+}, \mathrm{Er}^{3+} / \mathrm{TiO}_{2}$ [156]. An improvement compared to $\mathrm{TiO}_{2}$ alone was observed and the influence of the core-shell structure as semiconductor was suggested. Core/double-shell were subsequently proposed by [157], 
consisting of $\beta-\mathrm{NaYF}_{4}: \mathrm{Er}^{3+}, \mathrm{Yb}^{3+}$ crystals as core, amorphous $\mathrm{SiO}_{2}$ as inner shell and anatase $\mathrm{TiO}_{2}$ as outer shell. The aim of the $\mathrm{SiO}_{2}$ inner shell is to isolate electrically the photoanode from the upconversion core, thereby reducing electron trapping caused by the $\mathrm{NaYF}_{4}: \mathrm{Er}^{3+}, \mathrm{Yb}^{3+}$ crystals.

Another example is based on $\mathrm{Yb}^{3+}, \mathrm{Er}^{3+}$ doped $\mathrm{TiO}_{2}$ nanoshells that allowed a gain in conversion of efficiency from $6.87 \%$ to $9.12 \%$ [158].

There have been other attempts to include upconverters in DSSC cells such as with $\beta-\mathrm{NaYF}_{4}: \mathrm{Yb}^{3+}, \mathrm{Er}^{3+}$ but the reported upconversion EQE or current density improvement were lower than $0.02 \%$ and 0.2 $\mathrm{mA} / \mathrm{cm}^{2}$ (at 29 suns) [124].

Adding the upconversion functionality does not necessarily require to modify the fabrication process of the DSSC cell, as for example colloidal $\beta-\mathrm{NaYF}_{4}: 2 \% \mathrm{Er}^{3+}, 20 \% \mathrm{Yb}^{3+}$ nanoparticles were inserted in the $\mathrm{TiO}_{2}$ mesoporous layer of the DSSC [159].

\subsubsection{Organic solar cells}

Similarly, attempts with organic solar cells showed little improvement.

Upconversion has also been applied to organic solar cells such as P3HT-PCBM solar cells (P3HT: poly(3-hexylthiophene,), PCBM: [6,6]-phenyl-C61-butyric acid methyl ester). In the case of $\mathrm{YF}_{3}: \mathrm{Yb}^{3+}, \mathrm{Er}^{3+}$ an upconversion quantum efficiency of $0.19 \%$ was found under an excitation density of $250 \mathrm{~mW} / \mathrm{cm}^{2}$ [160]. Another example of $\mathrm{NaYF}_{4}: \mathrm{Yb}, \mathrm{Er}$ with P3HT:PCBM solar cells showed no improvement of conversion efficiency under the $\mathrm{AM} 1.5 \mathrm{G}$ spectrum [161]. $\mathrm{MoO}_{3}: \mathrm{Yb}^{3+}, \mathrm{Er}^{3+}$ was included in a P3HT-PCBM organic solar cell and led to an improvement of around $1 \%$ of the shortcircuit current under AM1.5 illumination [162].

There were attempts to use organic upconverters, such as a TTA system of PQ4PDNA/rubrene that provided an extra short circuit density of $0.3 \mathrm{~mA} / \mathrm{cm}^{2}$ under 48 sun [163].

In TTA upconversion, a pair of a sensitizer ion and an emitter ion are involved. Upon light excitation, the sensitizer has a transition from the ground level to a E2 level. Via an intersystem crossing process the sensitizer reaches the E1 level whose energy is then transferred by a Dexter energy transfer to the emitter ion in a E1 level. A second sensitizer is also excited and arrives in a E1 level. The corresponding energy is transferred to the emitter that reaches the E2 level. This E2 level decays radiatively and generates upconversion fluorescence.

\subsubsection{Strategies to improve upconversion yield}

Plasmonics has been proposed to enchance upconversion efficiency [164-166]. Often, gold nanoparticles are placed at proximity of the upconverting rare earth elements, with an effect either on the absorption of the rare earth element or on the emission due to changes of the local photonic density of states. The enhancement in upconversion depends on the distance between the rare earth elements and the metallic nanostructures. A 45-fold enhancement in upconversion efficiency was observed in $\mathrm{NaYF}_{4}: \mathrm{Yb}, \mathrm{Er}$ by adding Ag nanoparticles [167]. Plasmonics has also been implemented in upconversion for DSSC. For example, a core shell of $\beta-\mathrm{NaYF}_{4}: \mathrm{Er}^{3+}, \mathrm{Yb}^{3+} @ \mathrm{SiO}_{2}$ was proposed to be decorated with Au nanoparticles which enhanced the upconversion process thanks to plasmonic 
resonance [168]. This was enabled by the fact that the plasmonic resonance of Au was matching the upconversion emission in the green and red.

Another way of enhancement of upconversion efficiency is doping the host material with impurities, altering crystal symmetry of the host and the nature of the emitting ion neighbors. For example, a 25 -fold enhancement was obtained by doping $\mathrm{Y}_{2} \mathrm{O}_{3}: \mathrm{Yb}$;Er nanoparticles by Li+ [169].

As well, core-shell structures have been studied to enhance upconversion. They allow to passivate, reduce surface defects around the emitters and control their neighborhood. A 300-fold enhancement in upconversion efficiency was observed in $\mathrm{NaYF}_{4}: \mathrm{Yb}, \mathrm{Er} / \mathrm{CaF}_{2}$ core-shell nanoparticles in comparison to the nanoparticles without $\mathrm{CaF}_{2}$ [170]. Another example is based on $\mathrm{NaGdF}_{4}: \mathrm{Er}^{3+} @ \mathrm{NaGdF}_{4}: \mathrm{Ho}^{3+} @ \mathrm{NaGdF}_{4}$ core-shell-shell nanoparticles, that allowed combining upconversion of $\mathrm{Er}^{3+}$ with the one of $\mathrm{Ho}^{3+}$ [171].

\subsection{Conclusions}

While in theory upconversion should account for a large part of energy losses in a single bandgap solar cell, there are currently several drawbacks that prevent this concept from being used on a large scale. Firstly, the upconversion quantum yield of these materials is very low. Advanced concepts presented here such as plasmonics or impurity doping add another level of complexity in the systems which prevent a use on an industrial scale. Second, the absorption spectrum of the upconverters does not cover the broad near-infrared spectrum. A solution could be the use of several sensitizers for absorption, but as in the first case this adds complexity to the system.

\section{References}

[1] S. M. Bedair, M. F. Lamorte, J. R. Hauser, Appl. Phys. Lett. 34 (1979).

[2] M. Taguchi, K. Kawamoto, S. Tsuge, T. Baba, H. Sakata, M. Morizane, K. Uchihashi, N. Nakamura, S. Kiyama, O. Oota, Prog. Photovolt. - PROG Photovolt. 8 (2000) 503-513.

[3] A. Luque, A. Martí, Phys. Rev. Lett. 78 (1997) 5014-5017.

[4] B.S. Richards, Sol. Energy Mater. Sol. Cells 90 (2006) 1189-1207.

[5] F. Bella, G. Griffini, J.-P. Correa-Baena, G. Saracco, M. Grätzel, A. Hagfeldt, S. Turri, C. Gerbaldi, Science 354 (2016) 203-206.

[6] N. Yao, J. Huang, K. Fu, X. Deng, M. Ding, X. Xu, RSC Adv. 6 (2016) 17546-17559.

[7] E. Klampaftis, D. Ross, K.R. McIntosh, B.S. Richards, Sol. Energy Mater. Sol. Cells 93 (2009) 1182-1194.

[8] M.A. Green, Y. Hishikawa, W. Warta, E.D. Dunlop, D.H. Levi, J. Hohl-Ebinger, A.W.H. Ho-Baillie, Prog. Photovolt. Res. Appl. 25 (2017) 668-676.

[9] B. McKenna, R.C. Evans, Adv. Mater. 29 (2017) 1606491.

[10] X. Huang, S. Han, W. Huang, X. Liu, Chem. Soc. Rev. 42 (2013) 173-201.

[11] M.A. Green, Third Generation Photovoltaics: Advanced Solar Energy Conversion, Springer Science \& Business Media, 2003.

[12] R.B. Wehrspohn, U. Rau, A. Gombert, eds., Photon Management in Solar Cells: Wehrspohn/Photon Management in Solar Cells, Wiley-VCH Verlag GmbH \& Co. KGaA, Weinheim, Germany, 2015.

[13] W. Weber, J. Lambe, Appl. Opt. 15 (1976) 2299-2300. 
[14] A.-L. Joudrier, F. Proise, R. Grapin, J.-L. Pelouard, J.-F. Guillemoles, Energy Procedia 60 (2014) 173-180.

[15] X. Wang, T. Wang, X. Tian, L. Wang, W. Wu, Y. Luo, Q. Zhang, Sol. Energy 85 (2011) 21792184.

[16] T. Wang, J. Zhang, W. Ma, Y. Luo, L. Wang, Z. Hu, W. Wu, X. Wang, G. Zou, Q. Zhang, Sol. Energy 85 (2011) 2571-2579.

[17] T. Maruyama, A. Enomoto, K. Shirasawa, Sol. Energy Mater. Sol. Cells 64 (2000) 269-278.

[18] P. Campbell, M.A. Green, J. Appl. Phys. 62 (1987) 243-249.

[19] M.-L. Tsai, W.-C. Tu, L. Tang, T.-C. Wei, W.-R. Wei, S.P. Lau, L.-J. Chen, J.-H. He, Nano Lett. 16 (2016) 309-313.

[20] S. Zhuo, M. Shao, S.-T. Lee, Acs Nano 6 (2012) 1059-1064.

[21] C.-Y. Huang, D.-Y. Wang, C.-H. Wang, Y.-T. Chen, Y.-T. Wang, Y.-T. Jiang, Y.-J. Yang, C.-C. Chen, Y.-F. Chen, Acs Nano 4 (2010) 5849-5854.

[22] B.S. Richards, Sol. Energy Mater. Sol. Cells 90 (2006) 1189-1207.

[23] B.M. van der Ende, L. Aarts, A. Meijerink, Phys. Chem. Chem. Phys. 11 (2009) 11081-11095.

[24] J.-C.G. Buenzli, S.V. Eliseeva, J. Rare Earths 28 (2010) 824-842.

[25] X. Huang, S. Han, W. Huang, X. Liu, Chem. Soc. Rev. 42 (2012) 173-201.

[26] G. Seybold, G. Wagenblast, Dyes Pigments 11 (1989) 303-317.

[27] E. Klampaftis, D. Ross, S. Seyrling, A.N. Tiwari, B.S. Richards, Sol. Energy Mater. Sol. Cells 101 (2012) 62-67.

[28] X. Michalet, F.F. Pinaud, L.A. Bentolila, J.M. Tsay, S. Doose, J.J. Li, G. Sundaresan, A.M. Wu, S.S. Gambhir, S. Weiss, Science 307 (2005) 538-544.

[29] A. Vogler, H. Kunkely, Transit. Met. Rare Earth Compd. Excit. States Transit. Interact. I 213 (2001) 143-182.

[30] A.P. Green, A.R. Buckley, Phys. Chem. Chem. Phys. 17 (2014) 1435-1440.

[31] N. Goswami, Q. Yao, Z. Luo, J. Li, T. Chen, J. Xie, J. Phys. Chem. Lett. 7 (2016) 962-975.

[32] M.Y. Wong, E. Zysman-Colman, Adv. Mater. 29 (2017) 1605444.

[33] Z. Yang, Z. Mao, Z. Xie, Y. Zhang, S. Liu, J. Zhao, J. Xu, Z. Chi, M.P. Aldred, Chem. Soc. Rev. 46 (2017) 915-1016.

[34] Kwon Ji Eon, Park Soo Young, Adv. Mater. 23 (2011) 3615-3642.

[35] P.J. Sánchez-Illescas, P. Carpena, P. Bernaola-Galván, M. Sidrach-de-Cardona, A.V. Coronado, J.L. Álvarez, Sol. Energy Mater. Sol. Cells 92 (2008) 323-331.

[36] D. Cozza, C.M. Ruiz, D. Duché, S. Giraldo, E. Saucedo, J.J. Simon, L. Escoubas, Opt. Express 24 (2016) A1201.

[37] F. Proise, A.L. Joudrier, J.-L. Pelouard, J.-F. Guillemoles EUPV Proceedings (2012) 274-276.

[38] S. Woei Leow, C. Corrado, M. Osborn, M. Isaacson, G. Alers, S.A. Carter, J. Appl. Phys. 113 (2013) 214510.

[39] Correia Sandra F. H., Lima Patrícia P., Pecoraro Edison, Ribeiro Sidney J. L., André Paulo S., Ferreira Rute A. S., Carlos Luís D., Prog. Photovolt. Res. Appl. 24 (2016) 1178-1193.

[40] G. Griffini, F. Bella, F. Nisic, C. Dragonetti, D. Roberto, M. Levi, R. Bongiovanni, S. Turri, Adv. Energy Mater. 5 (2015) 1401312.

[41] V. Švrček, A. Slaoui, J.-C. Muller, Thin Solid Films 451-452 (2004) 384-388.

[42] C. Struempel, M. McCann, G. Beaucarne, V. Arkhipov, A. Slaoui, V. Svrcek, C. del Canizo, I. Tobias, Sol. Energy Mater. Sol. Cells 91 (2007) 238-249.

[43] V.T. Freitas, L. Fu, A.M. Cojocariu, X. Cattoën, J.R. Bartlett, R. Le Parc, J.-L. Bantignies, M. Wong Chi Man, P.S. André, R.A.S. Ferreira, L.D. Carlos, ACS Appl. Mater. Interfaces 7 (2015) 87708778.

[44] K. Machida, H. Li, D. Ueda, S. Inoue, G. Adachi, J. Lumin. 87-89 (2000) 1257-1259.

[45] Kaniyoor Adarsh, McKenna Barry, Comby Steve, Evans Rachel C., Adv. Opt. Mater. 4 (2015) 444-456.

[46] Y.H. Ghymn, K. Jung, M. Shin, H. Ko, Nanoscale 7 (2015) 18642-18650. 
[47] Y.-K. Liao, M. Brossard, D.-H. Hsieh, T.-N. Lin, M.D.B. Charlton, S.-J. Cheng, C.-H. Chen, J.-L. Shen, L.-T. Cheng, T.-P. Hsieh, F.-I. Lai, S.-Y. Kuo, H.-C. Kuo, P.G. Savvidis, P.G. Lagoudakis, Adv. Energy Mater. 5 (2015) 1401280.

[48] McKenna Barry, Evans Rachel C., Adv. Mater. 29 (2017) 1606491.

[49] C. Ji, K.-T. Lee, T. Xu, J. Zhou, H.J. Park, L.J. Guo, Adv. Opt. Mater. 5 (2017) UNSP 1700368.

[50] P. Spinelli, V.E. Ferry, J. van de Groep, M. van Lare, M.A. Verschuuren, R.E.I. Schropp, H.A. Atwater, A. Polman, J. Opt. 14 (2012) 024002.

[51] M.G. Debije, P.P.C. Verbunt, Adv. Energy Mater. 2 (2012) 12-35.

[52] V.K. Narasimhan, Y. Cui, Nanophotonics 2 (2013) 187-210.

[53] G. Qian, Z.Y. Wang, Chem.- Asian J. 5 (2010) 1006-1029.

[54] U. Resch-Genger, M. Grabolle, S. Cavaliere-Jaricot, R. Nitschke, T. Nann, Nat. Methods 5 (2008) 763-775.

[55] A. Yahia-Ammar, A.M. Nonat, A. Boos, J.-L. Rehspringer, Z. Asfari, L.J. Charbonnière, Dalton Trans. 43 (2014) 15583-15592.

[56] C.S. Erickson, L.R. Bradshaw, S. McDowall, J.D. Gilbertson, D.R. Gamelin, D.L. Patrick, ACS Nano 8 (2014) 3461-3467.

[57] J.-C.G. Bünzli, A.-S. Chauvin, in: J.-C.G. Bünzli, V.K. Pecharsky (Eds.), Handb. Phys. Chem. Rare Earths, Elsevier, 2014, pp. 169-281.

[58] J.-C.G. Bünzli, A.-S. Chauvin, Handb. Phys. Chem. Rare Earths (2014) 169-281.

[59] T. Fix, A. Nonat, D. Imbert, S. Di Pietro, M. Mazzanti, A. Slaoui, L.J. Charbonniere, Prog. Photovolt. 24 (2016) 1251-1260.

[60] H. Gallardo, G. Conte, P. Tuzimoto, A. Bortoluzzi, R.A. Peralta, A. Neves, Inorg. Chem. Commun. 10 (2008) 1292-1296.

[61] A. Gavriluta, T. Fix, A. Nonat, A. Slaoui, J.-F. Guillemoles, L. Charbonnière, Eur. J. Inorg. Chem. 44 (2017) 5318.

[62] T. Fukuda, S. Kato, E. Kin, K. Okaniwa, H. Morikawa, Z. Honda, N. Kamata, Opt. Mater. 32 (2009) 22-25.

[63] J. Garcia-Torres, P. Bosch-Jimenez, E. Torralba-Calleja, M. Kennedy, H. Ahmed, J. Doran, D. Gutierrez Tauste, L. Bautista, M.B. Della Pirriera, J. Photochem. Photobiol. Chem. 275 (2014) 103-113.

[64] E. Klampaftis, M. Congiu, N. Robertson, B.S. Richards, leee J. Photovolt. 1 (2011) 29-36.

[65] N.B.D. Lima, S.M.C. Goncalves, S.A. Junior, A.M. Simas, Sci. Rep. 3 (2013) 2395.

[66] O. Moudam, B.C. Rowan, M. Alamiry, P. Richardson, B.S. Richards, A.C. Jones, N. Robertson, Chem. Commun. (2009) 6649-6651.

[67] E.E.S. Teotonio, G.M. Fett, H.F. Brito, W.M. Faustino, G.F. de Sa, M.C.F.C. Felinto, R.H.A. Santos, J. Lumin. 128 (2008) 190-198.

[68] O.L. Malta, H.F. Brito, J.F.S. Menezes, F. Silva, C.D. Donega, S. Alves, Chem. Phys. Lett. 282 (1998) 233-238.

[69] H. Hovel, R. Hodgson, J. Woodall, Sol. Energy Mater. 2 (1979) 19-29.

[70] Nitto Eur. (n.d.).

[71] W. van Sark, A. Meijerink, R.E.I. Schropp, J. a. M. van Roosmalen, E.H. Lysen, Sol. Energy Mater. Sol. Cells 87 (2005) 395-409.

[72] K.R. McIntosh, G. Lau, J.N. Cotsell, K. Hanton, D.L. Bätzner, F. Bettiol, B.S. Richards, Prog. Photovolt. Res. Appl. 17 (2009) 191-197.

[73] D. Alonso-Alvarez, D. Ross, E. Klampaftis, K.R. McIntosh, S. Jia, P. Storiz, T. Stolz, B.S. Richards, Prog. Photovolt. 23 (2015) 479-497.

[74] S. Kalytchuk, S. Gupta, O. Zhovtiuk, A. Vaneski, S.V. Kershaw, H. Fu, Z. Fan, E.C.H. Kwok, C.-F. Wang, W.Y. Teoh, A.L. Rogach, J. Phys. Chem. C 118 (2014) 16393-16400.

[75] E. Klampaftis, D. Ross, G. Kocher-Oberlehner, B.S. Richards, leee J. Photovolt. 5 (2015) 584590.

[76] T. Fix, G. Ferblantier, H. Rinnert, A. Slaoui, Sol. Energy Mater. Sol. Cells 132 (2015) 191-195. 
[77] J.-Y. Chen, C.K. Huang, W.B. Hung, K.W. Sun, T.M. Chen, Sol. Energy Mater. Sol. Cells 120 (2014) 168-174.

[78] W.-B. Hung, T.-M. Chen, Sol. Energy Mater. Sol. Cells 133 (2015) 39-47.

[79] J. Liu, K. Wang, W. Zheng, W. Huang, C.-H. Li, X.-Z. You, Prog. Photovolt. 21 (2013) 668-675.

[80] H. Kataoka, S. Omagari, T. Nakanishi, Y. Hasegawa, Opt. Mater. 42 (2015) 411-416.

[81] T. Monzon-Hierro, J. Sanchiz, S. Gonzalez-Perez, B. Gonzalez-Diaz, S. Holinski, D. Borchert, C. Hernandez-Rodriguez, R. Guerrero-Lemus, Sol. Energy Mater. Sol. Cells 136 (2015) 187-192.

[82] S. Gonzalez-Perez, J. Sanchiz, B. Gonzalez-Diaz, S. Holinski, D. Borchert, C. HernandezRodriguez, R. Guerrero-Lemus, Surf. Coat. Technol. 271 (2015) 106-111.

[83] A. Le Donne, M. Dilda, M. Crippa, M. Acciarri, S. Binetti, Opt. Mater. 33 (2011) 1012-1014.

[84] I. Levchuk, C. Wuerth, F. Krause, A. Osvet, M. Batentschuk, U. Resch-Genger, C. Kolbeck, P. Herre, H.P. Steinrueck, W. Peukert, C.J. Brabec, Energy Environ. Sci. 9 (2016) 1083-1094.

[85] M. Jalalah, Y.-H. Ko, F.A. Harraz, M.S. Al-Assiri, J.-G. Park, Nano Energy 33 (2017) 257-265.

[86] S.-W. Baek, J.-H. Shim, Y.-H. Ko, J.-S. Park, G.-S. Lee, M. Jalalah, M.S. Al-Assiri, J.-G. Park, J. Mater. Chem. A 3 (2015) 481-487.

[87] T. Maruyama, R. Kitamura, Sol. Energy Mater. Sol. Cells 69 (2001) 207-216.

[88] B.S. Richards, K.R. Mclntosh, Prog. Photovolt. Res. Appl. 15 (2007) 27-34.

[89] L. Danos, T. Parel, T. Markvart, V. Barrioz, W.S.M. Brooks, S.J.C. Irvine, Sol. Energy Mater. Sol. Cells 98 (2012) 486-490.

[90] D. Ross, E. Klampaftis, J. Fritsche, M. Bauer, B.S. Richards, Sol. Energy Mater. Sol. Cells 103 (2012) 11-16.

[91] S.D. Hodgson, W.S.M. Brooks, A.J. Clayton, G. Kartopu, V. Barrioz, S.J.C. Irvine, Nano Energy 2 (2013) 21-27.

[92] S.D. Hodgson, W.S.M. Brooks, A.J. Clayton, G. Kartopu, V. Barrioz, S.J.C. Irvine, Nano Energy 4 (2014) 1-6.

[93] G.C. Glaeser, U. Rau, Thin Solid Films 515 (2007) 5964-5967.

[94] A. Solodovnyk, C. Kick, A. Osvet, H.-J. Egelhaaf, E. Stern, M. Batentschuk, K. Forberich, C.J. Brabec, Energy Technol. 4 (2016) 385-392.

[95] A. Solodovnyk, C. Kick, A. Osvet, H.-J. Egelhaaf, E. Stern, M. Batentschuk, K. Forberich, C.J. Brabec, Energy Technol. 4 (2016) 385-392.

[96] A. Gavriluta, T. Fix, A. Nonat, M. Paire, A. Slaoui, L.J. Charbonniere, J.-F. Guillemoles, Adv. Opt. Mater. 4 (2016) 1846-1853.

[97] K. Bouras, G. Schmerber, H. Rinnert, D. Aureau, H. Park, G. Ferblantier, S. Colis, T. Fix, C. Park, W.K. Kim, A. Dinia, A. Slaoui, Sol. Energy Mater. Sol. Cells 145 (2016) 134-141.

[98] N. Chander, S.K. Sardana, P.K. Parashar, A.F. Khan, S. Chawla, V.K. Komarala, IEEE J. Photovolt. 5 (2015) 1373-1379.

[99] C. Chen, H. Li, J. Jin, X. Chen, Y. Cheng, Y. Zheng, D. Liu, L. Xu, H. Song, Q. Dai, Adv. Energy Mater. 7 (2017) 1700758.

[100] J. Kettle, N. Bristow, D.T. Gethin, Z. Tehrani, O. Moudam, B. Li, E.A. Katz, G.A. dos Reis Benatto, F.C. Krebs, Sol. Energy Mater. Sol. Cells 144 (2016) 481-487.

[101] P. Vergeer, T.J.H. Vlugt, M.H.F. Kox, M.I. den Hertog, J. van der Eerden, A. Meijerink, Phys. Rev. B 71 (2005) 014119.

[102] B.M. van der Ende, L. Aarts, A. Meijerink, Phys. Chem. Chem. Phys. 11 (2009) 11081-11095.

[103] S. Li, Q. Huang, Y. Jiang, M. Hu, J. Nanosci. Nanotechnol. 16 (2016) 3679-3683.

[104] J. Chen, H. Guo, Z. Li, H. Zhang, Y. Zhuang, Opt. Mater. 32 (2010) 998-1001.

[105] X. Liu, X. Hu, H. Miao, G. Zhang, J. Mu, T. Han, D. Zhang, Sol. Energy 134 (2016) 45-51.

[106] B.M. van der Ende, L. Aarts, A. Meijerink, Adv. Mater. 21 (2009) 3073-3077.

[107] M.B. de la Mora, O. Amelines-Sarria, B.M. Monroy, C.D. Hernandez-Perez, J.E. Lugo, Sol. Energy Mater. Sol. Cells 165 (2017) 59-71.

[108] D. Timmerman, I. Izeddin, P. Stallinga, I.N. Yassievich, T. Gregorkiewicz, Nat. Photonics 2 (2008) 105-109. 
[109] D.-C. Yu, R. Martin-Rodriguez, Q.-Y. Zhang, A. Meijerink, F.T. Rabouw, Light-Sci. Appl. 4 (2015) e344.

[110] X. Wei, S. Huang, Y. Chen, C. Guo, M. Yin, W. Xu, J. Appl. Phys. 107 (2010) 103107.

[111] A. Kuzmanoski, V. Pankratov, C. Feldmann, J. Lumin. 179 (2016) 555-561.

[112] G. Lakshminarayana, J. Qju, J. Alloys Compd. 481 (2009) 582-589.

[113] Y. Tai, X. Li, B. Pan, J. Lumin. 195 (2018) 102-108.

[114] H. Lian, Z. Hou, M. Shang, D. Geng, Y. Zhang, J. Lin, Energy 57 (2013) 270-283.

[115] T. Trupke, M.A. Green, P. Wurfel, J. Appl. Phys. 92 (2002) 1668-1674.

[116] O. Maalej, J. Merigeon, B. Boulard, M. Girtan, Opt. Mater. 60 (2016) 235-239.

[117] X. Huang, S. Han, W. Huang, X. Liu, Chem Soc Rev 42 (2013) 173-201.

[118] T. Fix, J.-L. Rehspringer, H. Rinnert, A. Slaoui, Sol. Energy Mater. Sol. Cells 133 (2015) 87-91.

[119] D. Zhou, D. Liu, G. Pan, X. Chen, D. Li, W. Xu, X. Bai, H. Song, Adv. Mater. 29 (2017) 1704149.

[120] J.F. Liu, Q.H. Yao, Y.D. Li, Appl. Phys. Lett. 88 (2006) 173119.

[121] N. Bloembergen, Phys. Rev. Lett. 2 (1959) 84.

[122] F. Auzel, Chem. Rev. 104 (2003) 139-174.

[123] Gibart P, Auzel F, Guillaume J-C, Zahraman K, Jpn J Appl Phys 351 (1996) 4401-4402.

[124] J. C. Goldschmidt and S. Fischer, Adv. Optical Mater. 3 (2015) 510.

[125] P. Ramasamy, P. Manivasakan and J. Kim, RSC Adv. 4 (2014) 34873.

[126] V. Badescu, J. Appl. Phys. 104 (2008) 113120.

[127] T. Trupke and M. A. Green, J. Appl. Phys. 92 (2002) 4117.

[128] C. M. Johnson, G. J. Conibeer, J. Appl. Phys. 112 (2012) 103108.

[129] N. Souri, P. Tian, C. Platas-Iglesias, K.-L. Wong, A. Nonat and L. J. Charbonnière, J. Am. Chem. Soc. 139 (2017) 1456-1459.

[130] B. S. Richards, A. Shalav, IEEE Trans Electron Devices 54 (2007) 2679.

[131] S. K. MacDougall, A. Ivaturi, J. Marques-Hueso, K. W. Krämer and B. S. Richards, Sol. Energ. Mat. Sol. Cells 128 (2014) 18.

[132] S. Fischer, R. Martin-Rodriguez, B. Fröhlich, K. W. Krämer, A. Meijerink, J. C. Goldschmidt, J. Lumin. 153 (2014) 281.

[133] S. Fischer, E. Favilla, M. Tonelli, J. C. Goldschmidt, Sol. Energ. Mat. Sol. Cells 136 (2015) 127.

[134] A. Shalav, B. S. Richards, T. Trupke, Appl. Phys. Lett. 86 (2005) 013505.

[135] R. Page, K. Schaffers, P. Waide, J. Tassano, S. Payne, W. Krupke, W. Bischel, J. Optical Soc. Am. 15 (1998) 996.

[136] W. G. J. H. M. van Sark, J. de Wild, J. K. Rath, A. Meijerink and R. E. Schropp, Nanoscale Research Letters 8 (2013) 81.

[137] S. Ivanova, F. Pellé, J. Optical Soc. Am. B 26 (2009) 1930.

[138] H. Guo, Q. Li, L. Ma, J. Zhao, J. Mater. Chem. 22 (2012) 15757.

[139] M. Penconi, F. Ortica, F. Elisei, P. L. Gentili, J. Lumin. 135 (2013) 265.

[140] P. B. Merkel, J. P. Dinnocenzo, J. Lumin. 129 (2009) 303.

[141] B. S. Richards, Sol. Energ. Mat. Sol. Cells 90 (2006) 2329-2337.

[142] M. Rüdiger, S. Fischer, J. Frank, A. Ivaturi, B. S. Richards, K. W. Krämer, M. Hermle, J. C. Goldschmidt, Sol. Energ. Mat. Sol. Cells 128 (2014) 57.

[143] S. Fischer, A. Ivaturi, B. Frohlich, M. Rudiger, A. Richter, K. W. Kramer, B. S. Richards, J. C. Goldschmidt, IEEE J. Photovoltaics 4 (2014) 183.

[144] R. Martín-Rodríguez, S. Fischer, A. Ivaturi, B. Froehlich, K. W. Krämer, J. C. Goldschmidt, B. S. Richards and A. Meijerink, Chem. Mater. 25 (2013) 1912.

[145] F. Lahoz, Opt. Lett. 33 (2008) 2982. 
[146] F. Lahoz, C. Perez-Rodriguez, S. E. Hernandez, I. R. Martin, V. Lavin, U. R. Rodriguez-Mendoza, Sol. Energy Mater. Sol. Cells 95 (2011) 1671.

[147] X. D. Zhang, X. Jin, D. F. Wang, S. Z. Xiong, X. H. Geng and Y. Zhao, Phys. Status Solidi C 7 (2010) 1128-1131.

[148] Z. Q. Li, X. D. Li, Q. Q. Liu, X. H. Chen, Z. Sun, C. Liu, X. J. Ye and S. M. Huang, Nanotechnology 23 (2012) 025402.

[149] J. de Wild, T. F. Duindam, J. K. Rath, A. Meijerink, W. G. J. H. M. van Sark and R. E. I. Schropp, IEEE J. Photovolt. 17 (2013) 17-21.

[150] W. M. Campbell, A. K. Burrell, D. L. Officer, K. W. Jolley, Coord. Chem. Rev. 248 (2004) 13631379.

[151] K. Kakiage, Y. Aoyama, T. Yano, K. Oya, J. I. Fujisawa and M. Hanaya, Chem. Commun. 51 (2015) 15894-15897.

[152] N. Yao, J. Huang, K. Fu, X. Deng, M. Ding and X. Xu, RSC Adv. 6 (2016) 17546-17559.

[153] G. B. Shan and G. P. Demopoulos, Adv. Mater. 22 (2010) 4373-4377.

[154] G. B. Shan, H. Assaaoudi and G. P. Demopoulos, ACS Appl. Mater. Interfaces 3 (2011) 32393243.

[155] J. Wu, J. Wang, J. Lin, Z. Lan, Q. Tang, M. Huang, Y. Huang, L. Fan, Q. Li and Z. Tang, Adv. Energy Mater. 2 (2012) 78-81.

[156] J. Zhang, H. Shen, W. Guo, S. Wang, C. Zhu, F. Xue, J. Hou, H. Su and Z. Yuan, J. Power Sources 226 (2013) 47-53.

[157] L. Liang, Y. Liu, C. Bu, K. Guo, W. Sun, N.Huang, T. Peng, B. Sebo, M. Pan, W. Liu, S. Guo and X. Zhao, Adv. Mater. 25 (2013) 2174-2180.

[158] X. Wu, G. Q. Lu and L. Wang, Adv. Energy Mater. 3 (2013) 704.

[159] C. Z. Yuan, G. Y. Chen, P. N. Prasad, T. Y. Ohulchanskyy, Z. J. Ning, H. Tian, L. C. Sund, J. Mater. Chem. 22 (2012) 16709-16713.

[160] H.-Q. Wang, B. Batentschuk, A. Osvet, L. Pinna and C. J. Brabec, Adv. Mater. 23 (2011) 26752680.

[161] J.-L. Wu, F.-C. Chen, S.-H. Chang, K.-S. Tan and H.-Y. Tuan, Org. Electron. 13 (2012) 2104-2108.

[162] H. Q. Wang, T. Stubhan, A. Osvet, L. Pinna, C. J. Brabec, Adv. Mater. 23 (2011) 2675-2680.

[163] Y. Y. Cheng, B. Fueckel, R. W. MacQueen, T. Khoury, R. G. C. R. Clady, T. F. Schulze, N. J. EkinsDaukes, M. J. Crossley, B. Stannowski, K. Lips, T. W. Schmidt, Energ. Environ. Sci. 5 (2012) 6953.

[164] D. M. Wu, A. García-Etxarri, A. Salleo, J. A. Dionne, J. Phys. Chem. Lett. 5 (2014) 4020.

[165] H. Zhang, D. Xu, Y. Huang and X. Duan, Chem. Commun. 47 (2011) 979-981.

[166] W. Xu, S. Xu, Y. Zhu, T. Liu, X. Bai, B. Dong, L. Xu, and H. Song, Nanoscale 4 (2012) 6971-6973.

[167] M. Saboktakin, X. Ye, S. J. Oh, S.-H. Hong, A. T. Fafarman, U. K. Chettiar, N. Engheta, C. B. Murray and C. R. Kagan, ACS Nano 6 (2012) 8758-8766.

[168] P. Zhao, Y. Zhu, X. Yang, X. Jiang, J. Shen and C. Li, J. Mater. Chem. A 2 (2014) 16523-16530.

[169] G. Y. Chen, H. C. Liu, G. Somesfalean, Y. Q. Sheng, H. J. Liang, Z. G. Zhang, Q. Sun and F. P. Wang, Appl. Phys. Lett. 92 (2008) 113114.

[170] Y.-F. Wang, L.-D. Sun, J.-W. Xiao, W. Feng, J.-C. Zhou, J. Shen and C.-H. Yan, Chem.-Eur. J. 18 (2012) 5558-5564.

[171] D. Q. Chen, L. Lei, A. P. Yang, Z. X. Wang and Y. S. Wang, Chem. Commun. 48 (2012) 5898-5900. 